\title{
柴达木盆地西南缘新生代碎屑重矿物组合特征 及其古地理演化
}

李林林 ${ }^{(1 *}$ ，郭召杰 ${ }^{(1)}$ ，管树巍 ${ }^{(3)}$, 周苏平 ${ }^{(4)}$, 王明振 ${ }^{(1)}$, 房亚男 ${ }^{(1)}$, 张晨晨 ${ }^{(1)}$

(1) 北京大学造山带与地壳演化教育部重点实验室, 北京 100871;

(2) 北京大学石油与天然气研究中心, 北京 100871 ;

(3) 中国石油勘探开发研究院, 北京 100083;

(4) 青海油田公司勘探开发研究院, 敦煌 736202

*E-mail: lill@pku.edu.cn

收稿日期: 2014-07-25; 接受日期: 2014-12-25; 网络版发表日期: 2015-05-14

国家科技重大专项项目(编号: 2011ZX05009-001)资助

\begin{abstract}
摘要通过对柴达木盆地西南地区新生代地层中碎屑重矿物组合特征的分析发现，柴西 南重矿物组合具有典型分区特征, 反映区内主要受阿尔金山和祁漫塔格-东昆仑山两大物源 体系的控制。其中干柴沟-狮子沟-花土沟地区(A 区)物源主要来自阿尔金山地区，其重矿物 组合显示, 古新世至早始新世时期, 重矿物以锆石、钛的氧化物和硅灰石为主; 中晚始新世渐新世时期, 重矿物以不稳定矿物为主, 其中角闪石的含量显著增加; 晚渐新世-中新世以 来，重矿物仍以不稳定矿物为主，同时绿窝石含量明显增加，角闪石含量相应降低. 七个泉一 红柳泉地区(B区)物源受阿尔金山和祁漫塔格-东昆仑山双方向的控制，重矿物以绿穷石、石 榴石和角闪石等矿物为主. 绿草滩-东柴山-昆北地区 $(\mathrm{C}$ 区)物源主要来自祁漫塔格-东昆仑 山方向, 古近纪时期, 其重矿物以锆石和钛的氧化物为主, 晚渐新世-中新世以来, 石榴石、 绿窝石和角闪石等矿物的含量明显增加. 跃进-油砂山地区(D区)重矿物组合显示明显的混 合物源特征，指示物源来自多个方向. 柴西南新生代物源体系的演化指示，阿尔金山在古 新世-早始新世时期地形起伏不大, 物源区以低洼丘陵地貌为特征, 中晚始新世时期, 阿尔 金山开始快速隆升，并导致 A 区沉积物中不稳定矿物含量的增加. 阿尔金断裂古近纪时期 走滑速率缓慢，走滑位移量较小，晚渐新世-中新世时期以来，走滑速率显著增大，走滑位 移量超过 $300 \mathrm{~km}$. 祁漫塔格-东昆仑断裂带古近纪时期构造活动相对稳定, 祁漫塔格山地形 起伏较小, 晚渐新世-中新世以来, 构造活动开始活跃并导致了祁漫塔格山的强烈隆升.
\end{abstract}

关键词

柴达木盆地西南

新生代

重矿物组合

物源分析

古地理演化
柴达木盆地位于青藏高原东北缘, 被昆仑山、祁 连山和阿尔金山所围限(图1(a)), 是青藏高原北部最
大的中、新生代陆相含油气盆地. 其完整的新生代沉 积地层记录了新生代以来印度和欧亚板块碰撞及青

\footnotetext{
中文引用格式: 李林林, 郭召杰, 管树巍, 周苏平, 王明振, 房亚男, 张晨晨. 2015. 柴达木盆地西南缘新生代碎屑重矿物组合特征及其古地理演化. 中国科 学: 地球科学, 45: 780-798

英文引用格式: Li L L, Guo Z J, Guan S W, Zhou S P, Wang M Z, Fang Y N, Zhang C C. 2015. Heavy mineral assemblage characteristics and the Cenozoic paleogeographic evolution in southwestern Qaidam Basin. Science China: Earth Sciences, 58: 859-875, doi: 10.1007/s11430-014-5050-x
} 
藏高原隆升的重要信息(Yin等, 2008a). 青藏高原的 碰撞隆升过程一直都是地学家关注的焦点(Harrison 等, 1992; Owens 和Zandt, 1997; Zhu 和 Helmberger, 1998; Yin和Harrison, 2000; Jolivet等, 2001; Tapponnier 等, 2001; DeCelles等, 2002; Kapp等, 2003; 任收麦等, 2006; Royden等, 2008; Zhang等, 2013), 而对柴达木 盆地沉积过程和构造演化的研究, 对于解释青藏高 原北缘主要构造带的构造演化(Yin等, 2007, 2008a, $2008 b$; 肖安成等, 2013)及青藏高原隆升过程(袁四化 等, 2008; 付玲等, 2012; Song等, 2013; 吴婵等, 2013) 具有重要指示意义.

柴达木盆地西南地区(简称柴西南)位于阿尔金 山和祁漫塔格-东昆仑山之间, 北部以英雄岭为界, 是柴达木盆地油气勘探的重点区域, 也是构造作用 最为复杂的区域之一, 其新生代沉积过程受到了阿 尔金和祁漫塔格-东昆仑断裂带的共同作用控制. 而 关于阿尔金和东昆仑断裂带的构造演化过程, 目前 尚未形成统一的认识. 刘永江等(2007)提出, 阿尔金 断裂带自170 Ma左右开始活动, 并在之后发生多期 脉冲式走滑, 同时走滑活动与阿尔金山的隆升过程 具有密切的成因关系. 陈正乐等(2006)研究发现, 阿 尔金山存在多期次、多阶段的差异隆升过程. Ritts等 (2000)、Yue等(2003，2005)和Darby等(2005)认为阿尔 金断裂在渐新世-中新世时期, 走滑速率达到 $17 \mathrm{~mm} / \mathrm{a}$, 并可以向北一直延伸至阿拉善地区, 而中新世以来, 走滑速率减小为 $10 \mathrm{~mm} / \mathrm{a}$, 整个新生代阿尔金断裂走 滑位移在 $400 \mathrm{~km}$ 左右. Yin等(2002)则认为阿尔金断 裂自 $49 \mathrm{Ma}$ 至今以稳定的速率走滑, 走滑位移在 470 $\mathrm{km}$ 左右. 而吴否等 $(2012,2013)$ 、肖安成等(2013)认为 阿尔金断裂在晚始新世-中新世以前, 以基底剪切作 用导致的近东西向隆升为主, 大规模走滑活动起始 于15 Ma左右. 另一方面, 对于祁漫塔格-东昆仑断裂 带及其与柴西南南缘构造关系的研究也存在不同的 认识. Yin等(2007)提出, 柴达木盆地南部边界在新生 代早期可以一直向南延伸至可可西里地区, 直至晚 渐新世时期, 柴达木盆地的南部边界才逐渐封闭. 而 关于柴西南与祁漫塔格-东昆仑山的边界关系, 前人 则存在向南逆冲 (Burchfiel等, 1989; Tapponnier等, 2001; Jolivet等, 2003)和向北逆冲(Chen等, 1999; Yin 等, 2007; Wang等, 2011)两种不同的模型.

物源分析是恢复沉积作用过程、重建古地理环境
重要内容, 物源的位置和性质、沉积物搬运路径等研 究, 对于盆地构造演化研究具有重大意义(Pettijohn, 1957; 王成善和李祥辉, 2003; Weltje和von Eynatten, 2004; 王建刚和胡修棉, 2008). 碎屑重矿物是沉积物 源信息的重要载体, 不同物源母岩对应于不同的重 矿物种类(Pettijohn等, 1987), 重矿物是最为敏感的沉 积物源指示剂之一(Morton, 1985), 早在19世纪中后 期, 地质学家就已经发现了重矿物对物源的重要指 示意义(Weltje和von Eynatten, 2004). 然而由于沉积 物中重矿物特征受到母岩、风化搬运和沉积成岩等复 杂地质条件的影响(Morton和Hallsworth, 1994), 单一 重矿物特征在物源分析过程中往往由于多因素的复 杂影响, 而不能真实反映物源信息, 因此, 重矿物组 合和单矿物原位分析等方法逐渐兴起, 并得到了广 泛应用(Hubert, 1962; Mange和Maurer, 1992; Morton 和 Hallsworth, 1999; 吴朝东等, 2005; 徐亚军等, 2007; 刘群明等, 2011; Garzanti等, 2012, 2013).

本文基于柴西南油气勘探开发过程中积累的大 量重矿物数据, 开展对柴西南新生代重矿物组合特 征的详细分析, 同时结合前人对柴达木盆地的大量 研究, 对柴西南新生代物源体系的特征和演化过程 进行解析, 对控制柴西南盆地边界的阿尔金和东昆 仑断裂带新生代构造作用进行重点解析, 进而恢复 柴西南地区新生代古地理演化过程.

\section{1 地质背景}

柴达木盆地北以祁连山-南山冲断带为界, 南以 祁漫塔格-东昆仑断裂带为界, 西为阿尔金断裂带, 整体表现为三角形的几何形态(图1(a)). 盆地及其邻 区中、新生代处于特提斯洋活动带和印度与西伯利亚 两大板块碰撞构造带的前缘(吕宝风等, 2011), 长期 受特提斯洋闭合及青藏高原隆升的驱动, 构造活动 复杂. 柴达木盆地保留了完整的新生代沉积, 巨厚的 沉积地层记录了柴达木盆地完整的新生代演化过程, 因此吸引了大批学者的关注(Dupont-Nivet等, 2002, 2004; Rieser等, 2005, 2009; 尹成明等, 2007; 王艳清 等, 2012).

柴西南地区是柴达木盆地重要的油气富集区, 具有非常优越的石油地质条件(马达德等, 2005). 同 时柴西南地区也是构造活动频繁、构造演化历史复杂 


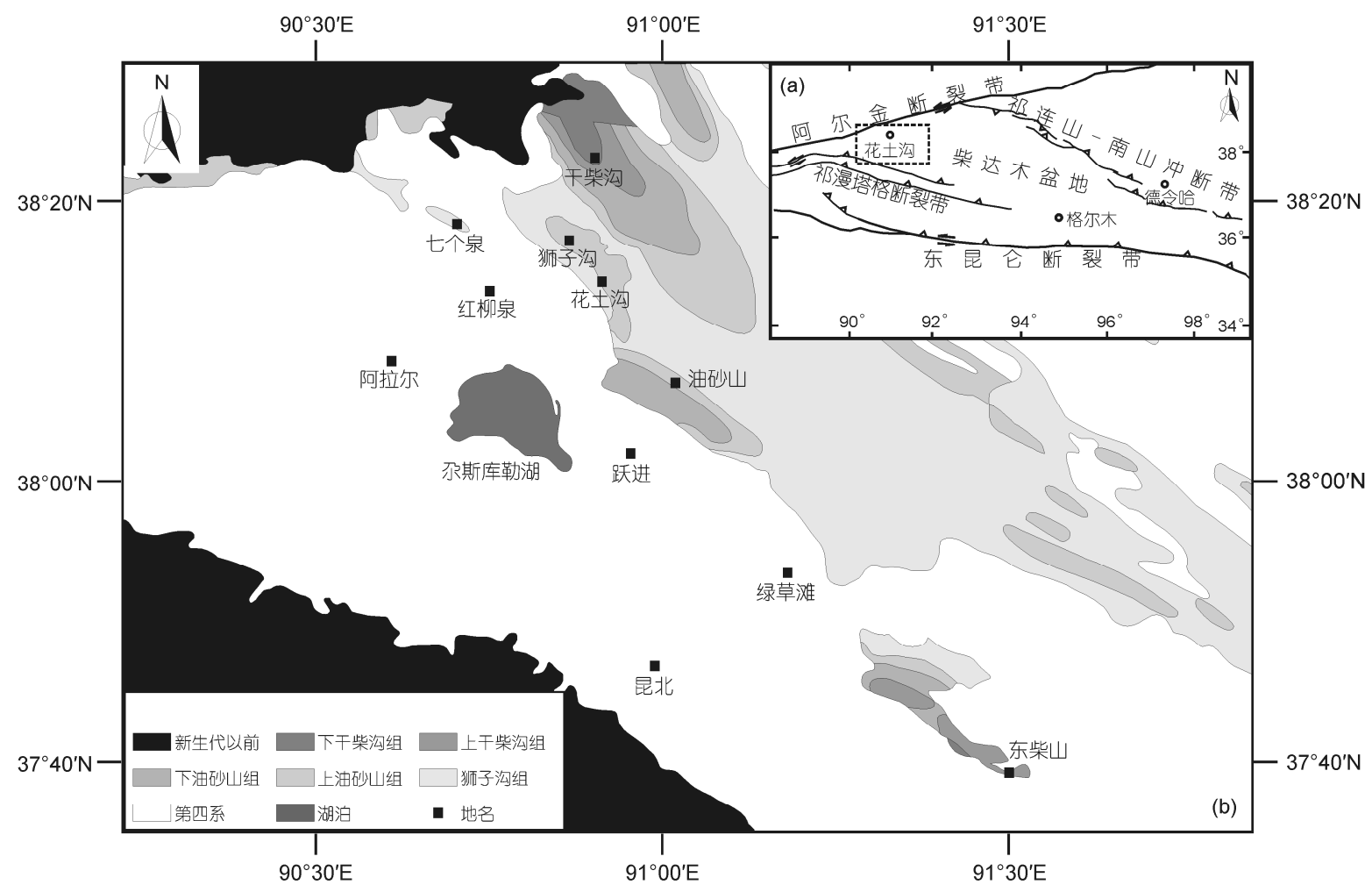

图 1 柴木盆地及周缘构造纲要图(a)及柴西南地区区域地质简图(b)

的区域, 与柴北缘自古新世以来区内主要受祁连山南山逆冲作用控制(刘志宏等, 2005; Yin等, 2008a)不 同，柴西南地区受阿尔金和祁漫塔格-东昆仑断裂带 的共同控制，构造的复杂性导致了对于柴西南构造沉积关系认识的局限.

柴西南巨厚的新生代沉积地层记录了阿尔金和 祁漫塔格-东昆仑断裂带的复杂构造演化过程, 是研 究阿尔金断裂走滑活动(吴磊等, 2012, 2013)和祁漫 塔格-东昆仑断裂带构造活动(Yin等, 2007)的重要场 所，同时对于指示青藏高原北缘的隆升及印藏碰撞 在高原北缘的响应具有重要意义. 其中沉积物中碎 屑重矿物对于物源的指示意义可以有效揭示构造作用 控制下物源体系的演化特征, 对于恢复柴西南新生代 沉积充填历史和反演断裂带的活动历史至关重要.

\section{2 柴西南新生代沉积充填序列}

蒋宏忱等(2003)、赵加凡等(2004)、惠博等(2011) 和付玲等(2012)对柴达木盆地新生代沉积特征已经
进行了大量研究. 基于野外露头、钻井及地震剖面等 多种资料的结合，对柴西南地区沉积充填序列和沉 积体系演化的综合分析认为, 柴西南新生代主要以 陆相河流-湖泊沉积环境为主, 发育了一系列河流、三 角洲和湖泊沉积体系, 主要的新生代地层单元如图2 所示.

柴西南大部分地区均被第四系沉积物所覆盖, 仅在边缘零星出露古近系和新近系地层(图1(b)), 其 中路乐河组和下干柴沟组底部地层在露头区均未出 露, 其他地层出露良好. 柴西南地区新生代沉积过程 主要受阿尔金和东昆仑断裂带及其引发的次级构造 作用的控制，整个新生代，盆地的充填演化主要经历 了盆地形成、盆地稳定沉降和盆地衰亡三个阶段.

路乐河组地层直接不整合覆盖在基底之上，是 柴西南地区最早的新生代沉积记录, 代表了盆地的 初始形成阶段. 路乐河组以棕红色粗碎屑砂砾岩为 主(图3(a)), 沉积物砾、砂、泥混杂，分选性和磨圆度 中等-差(付玲等，2012), 以广泛发育冲积扇、河流沉 积为特征. 在七个泉和狮子沟一带的狭小区域内, 路 


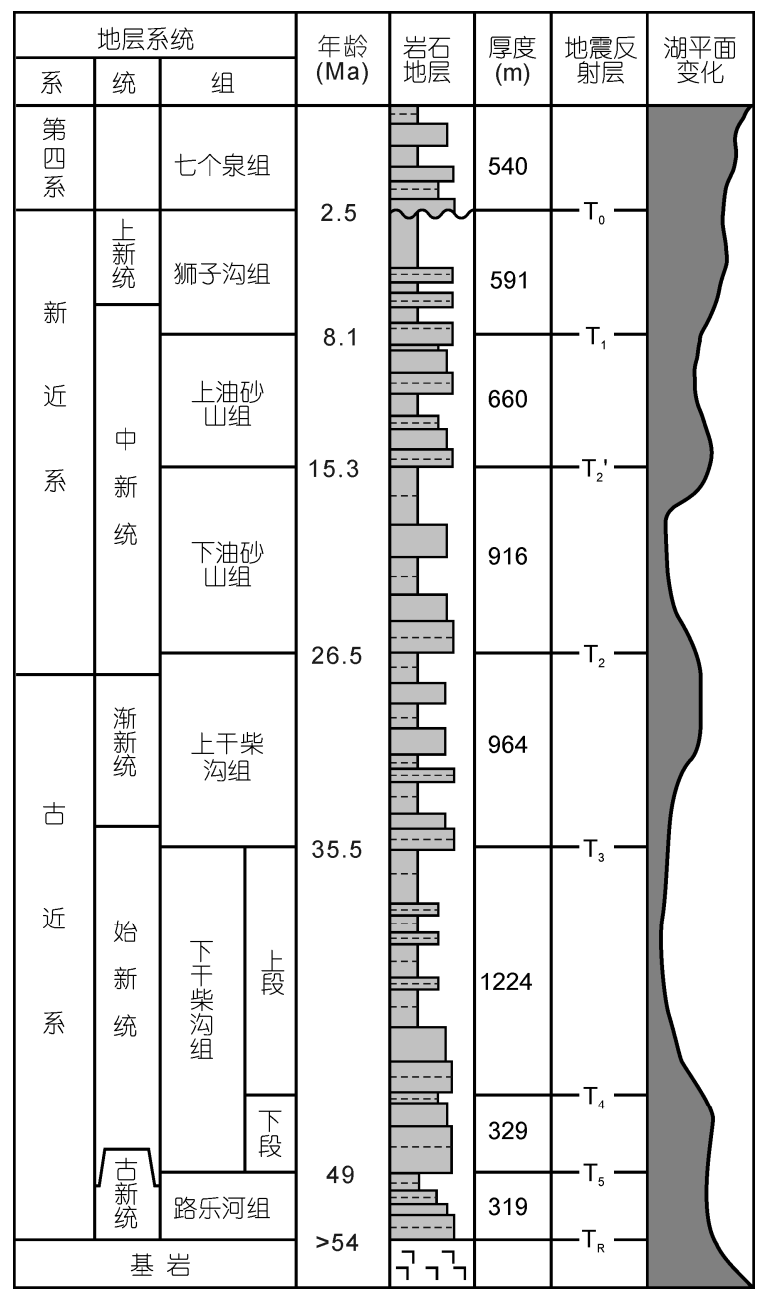

图 2 柴西南新生代沉积充填序列

地层年龄数据分别来自路乐河组(>54 49 Ma)(Yin 等, 2007, 2008a, 2008b), 下干柴沟组(>35.5 Ma)及上干柴沟组(35.5 26.5 Ma)(Sun 等, 2005), 下油砂山组(26.5 15.3 Ma)、上油砂山组(15.3 8.1 Ma)和狮子 沟组(8.1 2.5 Ma)(Fang 等, 2007)

乐河组表现为灰色䥻质泥岩、泥岩与砂岩、砾岩互层, 指示了间歇性的湖盆扩张, 代表湖盆的沉积中心(柳 祖汉等, 2006).

下干柴沟组可进一步划分为下干柴沟组下段和 下干柴沟组上段. 下干柴沟组下段岩性由底部的粗 碎屑棕红色砂砾岩向上渐变为浅灰色中细砂岩、泥岩 (图3(b)). 反映了湖盆扩张, 湖水面积扩大的过程(赵 加凡等, 2004), 指示在经历了形成阶段的粗碎屑沉积 后, 盆地开始逐渐扩张并向稳定沉积阶段转换. 下干 柴沟组上段为一套细砂岩、泥岩、泥灰岩沉积(图3(c)), 部分地区发育碳酸盐岩沉积, 整体显示以湖泊细粒
沉积为主，指示湖盆进入稳定沉降阶段.

上干柴沟组沉积物以一套杂色细砂岩、泥岩、泥 灰岩为主(图3(d)), 指示滨浅湖沉积特征, 沉积物粒 度仍以细粒沉积为主, 主要以红层的发育为特征, 可 能与气候条件的变化有关. 同时伴随着红层的出现, 湖盆发生了一定的萎缩, 柴西南西部三角洲开始向 盆内进积, 但整体上柴达木盆地仍处于稳定沉降 阶段.

自晚渐新世-中新世以来, 柴达木盆地的沉积中 心开始向东迁移(赵加凡等, 2004; Yin等, 2008b), 柴 西南地区下油砂山组沉积时期, 沉积体系开始向三 角洲-河流沉积体系过渡, 湖盆范围逐渐萎缩. 其中 干柴沟地区以三角洲沉积为主(图3(e)), 沉积粒度比 上干柴沟组沉积时期明显变粗. 上油砂山组沉积粒 度进一步变粗(图3(f)), 三角洲-河流体系开始在柴西 南地区广泛发育, 湖盆的萎缩速度加快, 区内以褐红 色砂质沉积为主, 仅在盆地中心发育小范围细粒湖 相沉积. 晚中新世狮子沟组沉积以来, 伴随柴达木盆 地沉积中心的向东迁移, 柴西南地区湖相沉积完全 消失, 沉积物以快速堆积分选很差的砂泥岩为主, 表 现为河流和冲积扇沉积环境特征.

\section{3 重矿物形态与组合特征}

沉积物中, 碎屑重矿物的形态和组合特征是指 示物源信息的重要指标, 对碎屑重矿物形态特征的 观察, 可以对矿物经历的风化作用强度进行定性分 析(Andò等, 2012), 而重矿物组合特征的变化则可 以揭示物源体系的演化特征, 是物源分析的重要 方法.

\section{1 矿物形态特征}

对柴西南新生代露头及岩芯样品中碎屑重矿物 进行分类提取, 通过重液、电磁等方法, 分离出其中 的锆石、金红石、电气石和石榴石 4 种矿物. 对矿物 形态特征的观察发现(图4), 不同区域不同时代的碎 屑矿物显示相似的形态特征, 不存在明显的形态差 异, 锆石、金红石、电气石和石榴石主要以自形、半 自形结构为主, 颗粒表面以机械侵蚀为主, 化学风化 作用相对较弱, 仅石榴石表面显示较为明显的化学 侵蚀, 整体上矿物颗粒保留了较好的原始形态, 指示 

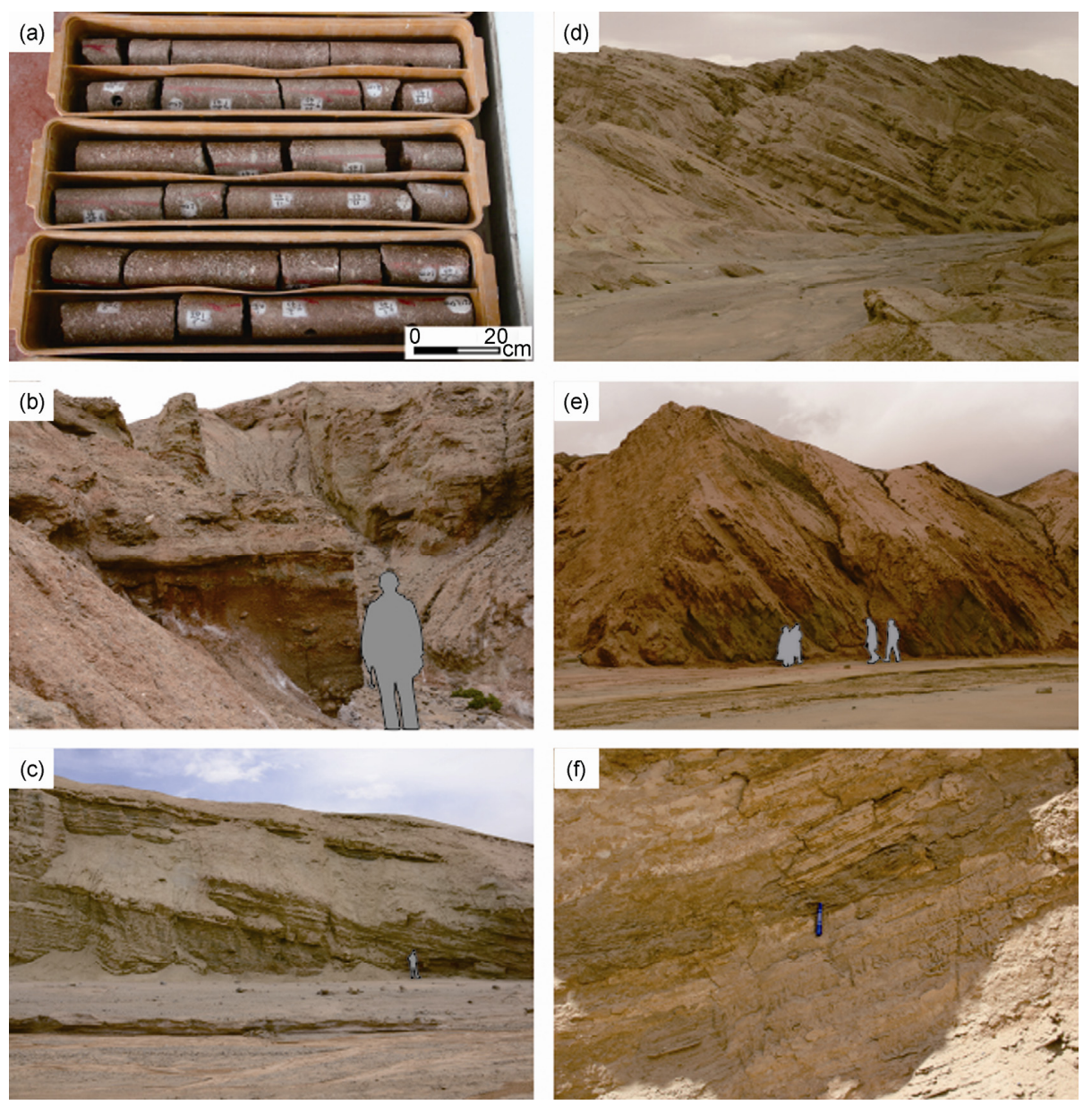

图 3 柴西南新生代不同时期沉积特征

(a) 昆北地区路乐河组岩芯特征, 发育大套厚层棕红色含砾粗砂岩; (b) 干柴沟地区下干柴沟组下段野外露头特征, 发育棕红色冲积扇粗碎 屑沉积, 倒粒序特征明显; (c) 干柴沟地区下干柴沟组上段野外露头特征, 以薄层灰绿色泥灰岩为主, 显示湖水较深, 沉积环境相对稳定; (d) 干柴沟地区上干柴沟组野外露头特征, 以杂色薄层泥岩、粉砂质泥岩、泥灰岩互层为特征, 红层的发育可能指示了气候的干旱化; (e) 干柴沟 地区下油砂山组野外露头特征, 以褐红色砂岩为主, 砂岩呈一定的延展性, 显示三角洲前缘河口坝沉积特征; (f) 狮子沟地区上油砂山组野 外露头特征, 沉积物以分选较差的砂泥混杂堆积为特征, 发育槽状交错层理, 显示河道沉积特征, 强烈的风化作用导致露头覆盖较为严重

碎屑矿物整体上经历了较弱的风化作用, 显示近源 搬运沉积特征.

碎屑锆石(图4(a))主要以长柱状矿物为主，粒径 主要集中在50 200 $\mu \mathrm{m}$, 粒径变化范围不大, 颗粒形 态主要以自形、半自形为主, 锆石晶形结构保存良好, 部分锆石显示较好的磨圆, 显示经历了较为长距离 的风化、搬运作用，不同晶形特征的锆石颗粒同时存 在，指示区域可能同时存在近源和远源两个物源体 系, 也可能与再旋回沉积物的加入有关. 金红石形态 特征显示(图4(b)), 金红石同样以长柱状矿物为主, 粒径主要集中在50 200 $\mu \mathrm{m}$, 粒径变化范围不大, 颗
粒形态也以自形、半自形为主，部分金红石显示较好 的磨圆特征，同样指示了两个不同搬运距离的物源 体系或再旋回沉积物质的加入. 电石气(图4(c))颗粒 粒径分布在50 300 $\mu \mathrm{m}$, 粒径变化范围较大, 颗粒形 态以自形柱状为主, 晶体结构保存较好, 晶体破裂面 以机械破碎为主, 说明电气石经历了较弱的风化作 用，指示近源物源特征. 石榴石(图4(d))颗粒粒径分 布在50 400 $\mu \mathrm{m}$ ，粒径变化范围同样较大，颗粒形态 以半自形粒状矿物为主, 颗粒表面显示有较为明显 的机械侵蚀和化学溶蚀作用, 颗粒表面结构的侵蚀 作用明显强于电气石、金红石和锆石矿物, 但石榴石 

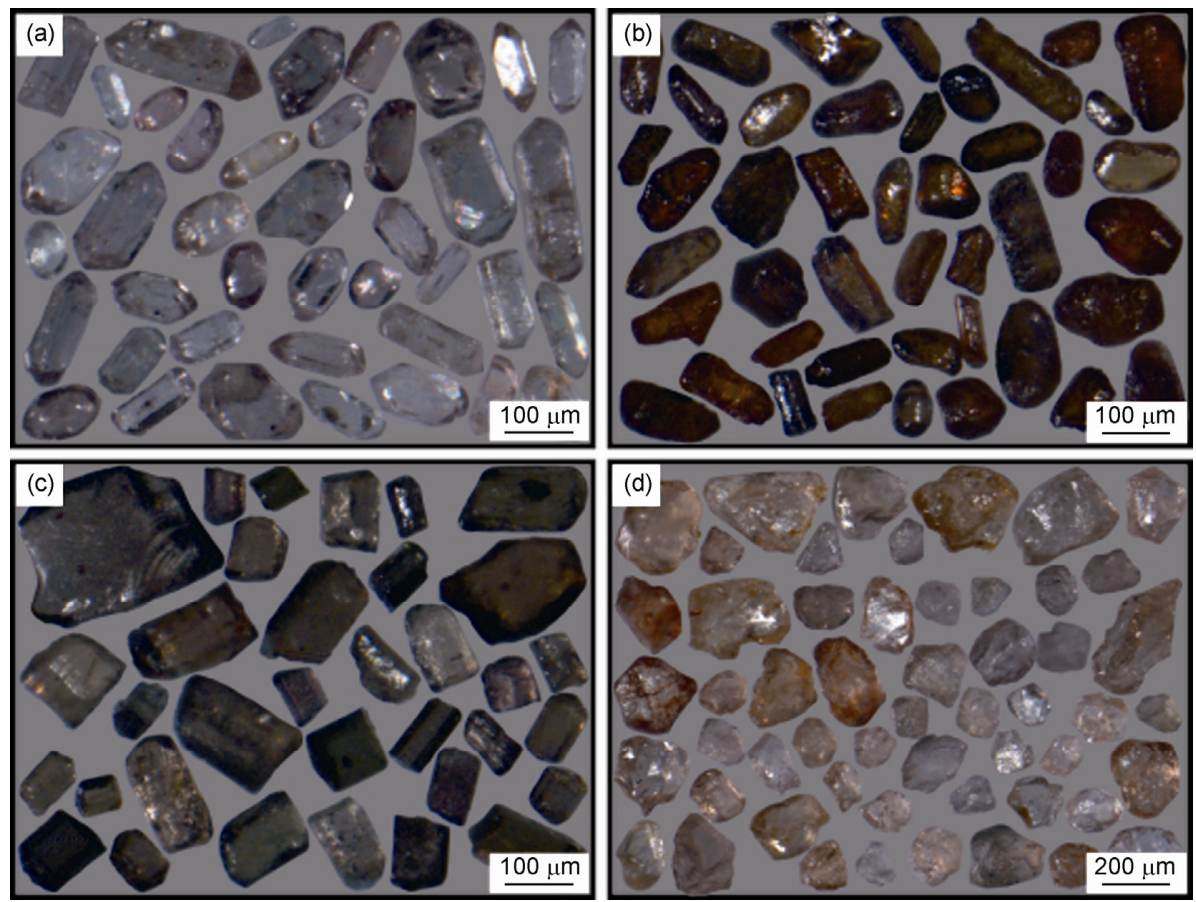

图 4 柴西南新生代碎屑重矿物显微特征

(a) 锆石; (b) 金红石; (c) 电气石; (d) 石榴石

颗粒表面仍然保留了原始的晶面结构特征, 说明风 化作用较弱, 而强于电石气等矿物的风化侵蚀可能 与石榴石相对较弱的矿物稳定性有关.

综合柴西南新生代碎屑矿物形态特征的初步分 析认为, 柴西南新生代整体以近源沉积为主, 沉积物 经历的风化作用强度不大, 矿物原始的晶体形态特 征得到了较好地保存, 而碎屑重矿物的大量保存为 重矿物物源分析提供了良好的基础. 有利于通过重 矿物组合特征的分析研究新生代物源体系特征.

\section{2 重矿物组合特征}

根据我国石油天然气行业标准《沉积岩重矿物分 离与鉴定方法》 (中国石油天然气总公司, 1997), 对柴 西南不同地区钻井过程中获取的样品进行重矿物分离 测试, 所有测试工作均由青海油田完成, 对原始4110 个测试结果, 进一步分析, 去除重晶石、磁铁矿等自生 矿物及不透明矿物, 并对剩余的透明碎屑矿物以 $100 \%$ 进行重新加权, 同时, 为了减小误差, 对同一井位相 同层位的多个样品进行算术平均, 以其平均值来指示 该井位特定层位的重矿物组合特征, 分析整理后的重 矿物数据见网络版附录1(http://earth.scichina.com).
柴西南地区大量岩芯重矿物分析结果显示, 柴 西南新生代透明重矿物以锆石、石榴石、绿帘石、角 闪石及钛的氧化物为主, 不同地区重矿物组合平面 展布存在一定的差异, 根据柴西南重矿物组合平面 分布特征的变化, 可以将柴西南地区大致划分为干 柴沟-狮子沟-花土沟 $(\mathrm{A})$ 、七个泉-红柳泉(B)、绿草滩东柴山-昆北(C)及跃进-油砂山(D)4个区域(图5).

柴西南路乐河组重矿物分布特征显示(图5), A区 重矿物以锆石、钛的氧化物及硅灰石为主，角闪石、 绿帘石及石榴石含量较低. B区重矿物以石榴石、绿 窝石和角闪石等矿物为主, 钛的氧化物和锆石含量 较低, 同时含有少量榍石. C区及D区重矿物组合特 征基本一致, 其重矿物均显示锆石、钛的氧化物含量 较高, 角闪石、绿帘石和石榴石含量较低, 同时含有 少量榍石.

下干柴沟组下段重矿物的区域分布规律发生了 一定变化(图6). A区重矿物组合仍以锆石、硅灰石及 钛的氧化物为主. B区重矿物仍以石榴石、绿帘石和角 闪石等矿物为主，但锆石和钛的氧化物含量比路乐 河组沉积时期有所增加. C区重矿物组合继承了路乐 河组沉积特征，重矿物以锆石、钛的氧化物为主，角 


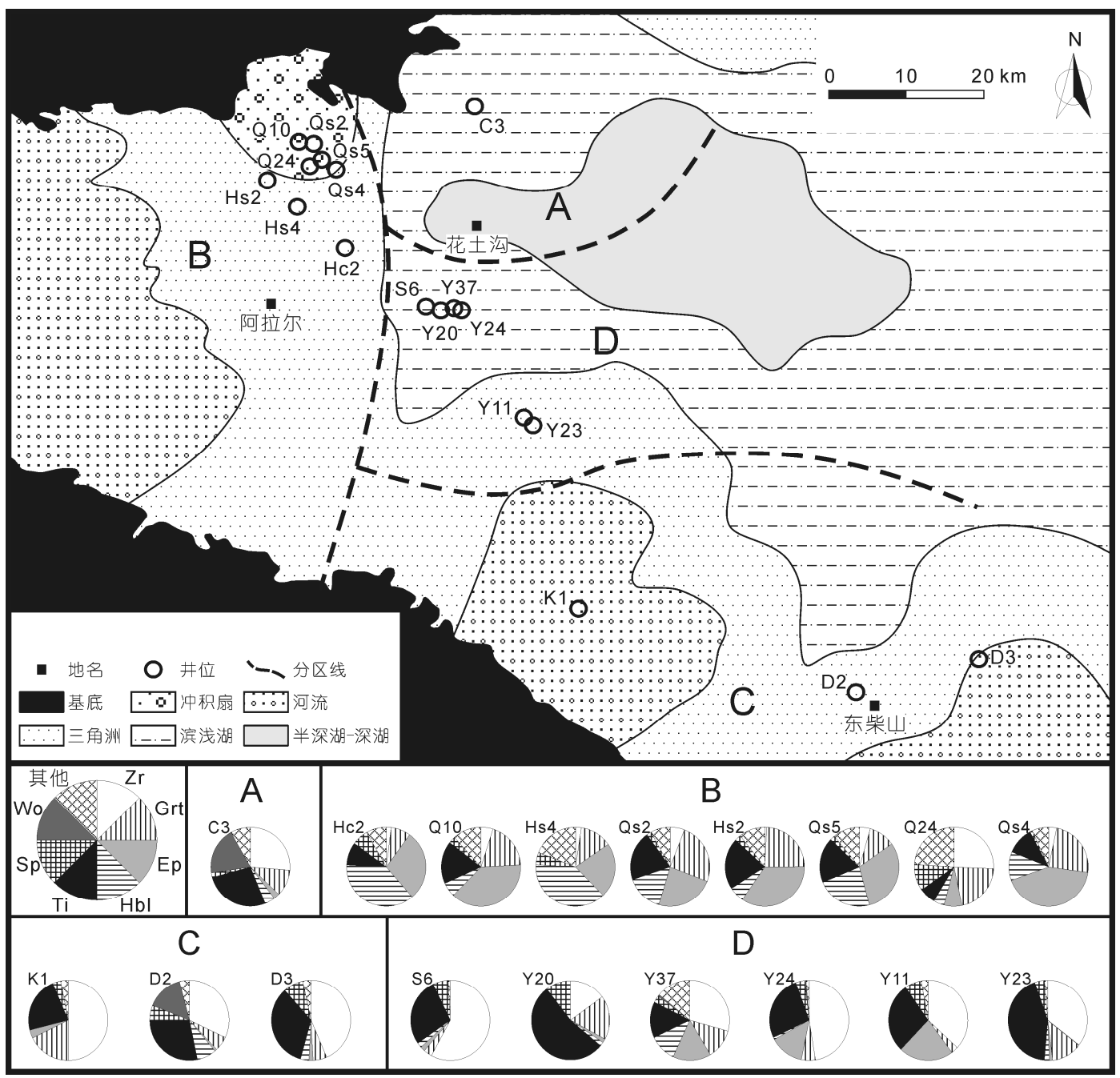

图 5 柴西南地区路乐河组沉积相展布及重矿物组合分布图

Zr: 锆石; Grt: 石榴石; Ep: 绿帘石; Hbl: 角闪石; Ti: 钣的氧化物; Sp: 榍石; Wo: 硅灰石. 下同

闪石、石榴石和绿帘石矿物的含量较低, 同时含有少 量榍石和硅灰石. D区重矿物以锆石和钛的氧化物为 主，同时含有少量石榴石、角闪石、绿帘石、榍石和 硅灰石，与路乐河组沉积时期相比，区内角闪石、石 榴石和绿帘石等矿物的含量明显增加.

下干柴沟组上段(图7)A区的重矿物组合特征发 生明显变化, 区内角闪石含量显著增加, 重矿物组合 以角闪石、石榴石等矿物为主, 锆石和钛的氧化物含 量明显降低, 同时部分区域硅灰石含量较高. 而 $\mathrm{B}$ 区 与 $\mathrm{A}$ 区相比, 绿帘石的含量明显较高, 角闪石含量相 对较低, 重矿物组合以绿窝石、角闪石和石榴石为主. C区稳定矿物锆石、钛的氧化物的含量比下干柴沟组
下段时期有所降低, 石榴石、角闪石及绿帘石的含量 略有增加. D区重矿物中锆石及钛的氧化物含量进一 步降低, 但依然明显高于 $\mathrm{B}$ 区，同时角闪石、石榴石 和绿帘石的含量明显高于 $\mathrm{C}$ 区, 榍石和硅灰石虽然含 量较低, 但在区内普遍存在.

上干柴沟组沉积时期, 重矿物组合继承了下干柴 沟组上段沉积时期的特点(图8). A区重矿物仍以角闪 石、石榴石等矿物为主, 绿帘石的含量略有增加, 锆石 和钛的氧化物含量很低, 其中角闪石含量明显高于其 他地区. B区以绿帘石、角闪石和石榴石等矿物为主, 其中绿帘石含量较高, 锆石、钛的氧化物含量很低. C 区重矿物以锆石、钛的氧化物和石榴石为主, 硅灰石含 


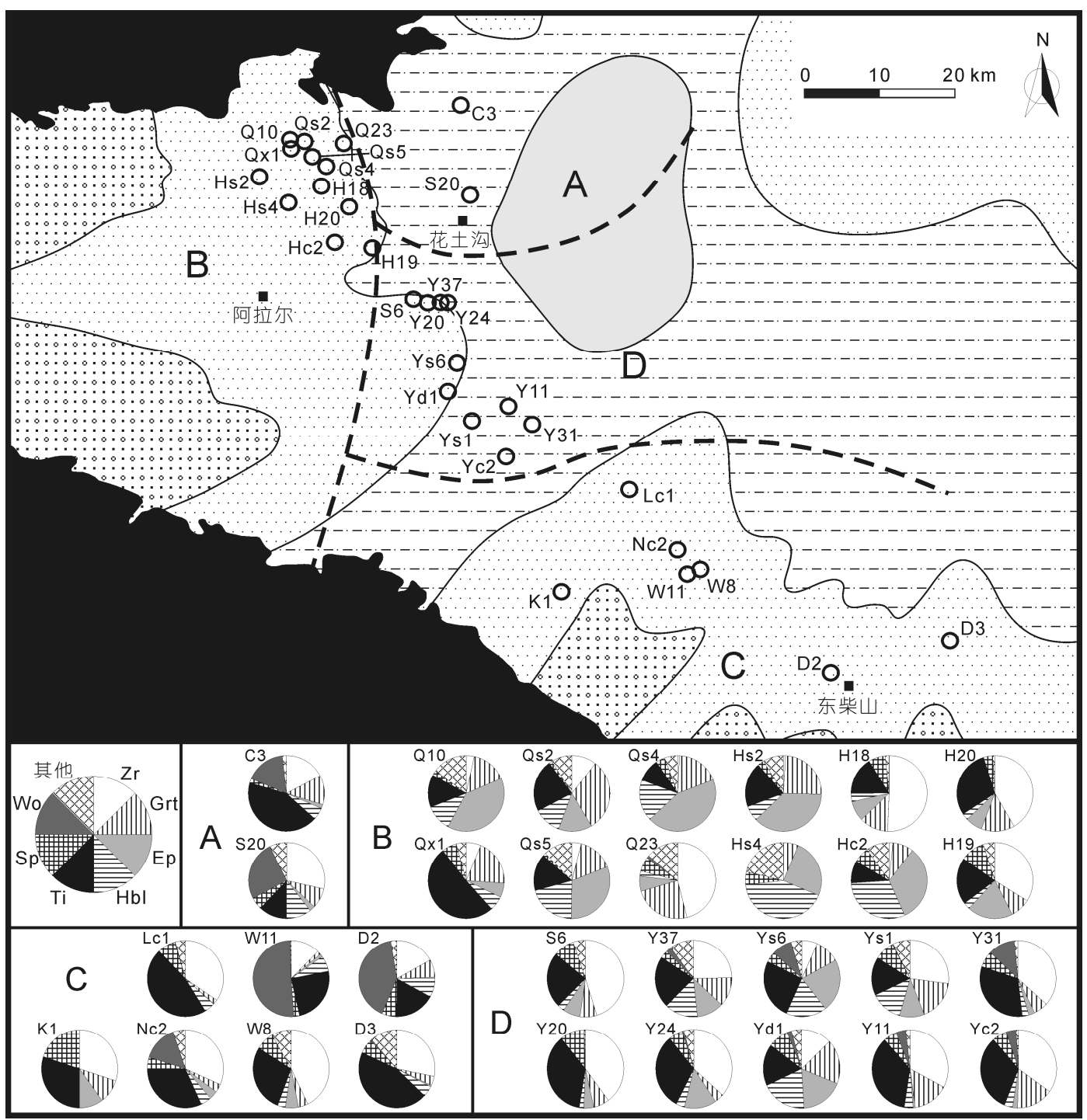

图 6 柴西南地区下干柴沟组下段沉积相展布及重矿物组合分布图

量也普遍较高, 同时还含有一定量的榍石. D区角闪 石、石榴石和绿帘石矿物的含量相比下干柴沟组上段 沉积时期有所增加, 锆石、钛的氧化物及硅灰石含量 有所降低, 但锆石、钛的氧化物等矿物含量依旧较高, 榍石的含量明显高于 $\mathrm{A}$ 区及 $\mathrm{B}$ 区, 而与 $\mathrm{C}$ 区相当.

下油砂山组沉积时期(图9), A区角闪石的含量显 著降低, 石榴石和绿帘石的含量明显增加, 重矿物组 合以石榴石、绿帘石、角闪石和钛的氧化物为主, 锆 石含量较低. B区仍以绿帘石含量较高为特征, 重矿 物组合以绿帘石、石榴石和角闪石等矿物为主, 锆 石、钛的氧化物含量较低, 同时含有少量榍石. C区重
矿物组合中, 不稳定重矿物的含量明显增加, 石榴石、 角闪石和绿帘石的含量占到了透明重矿物总量的一 半左右, 同时锆石的含量依然较高, 榍石的含量较上 干柴沟组沉积时期有所增加, 钛的氧化物含量降低, 硅灰石含量显著降低. $\mathrm{D}$ 区与 $\mathrm{B}$ 区具有相似的重矿物 组合特征, 但石榴石、锆石和榍石含量高于 $\mathrm{B}$ 区.

上油砂山组沉积时期(图10), B区重矿物组合以 绿穴石、石榴石、角闪石为主, 其中角闪石含量较低, 绿帘石含量较高, 锆石、钛的氧化物和榍石等重矿物 含量较低. C区重矿物则显示较高的锆石和榍石含量, 同时绿帘石、石榴石和角闪石含量与下油砂山组沉积 


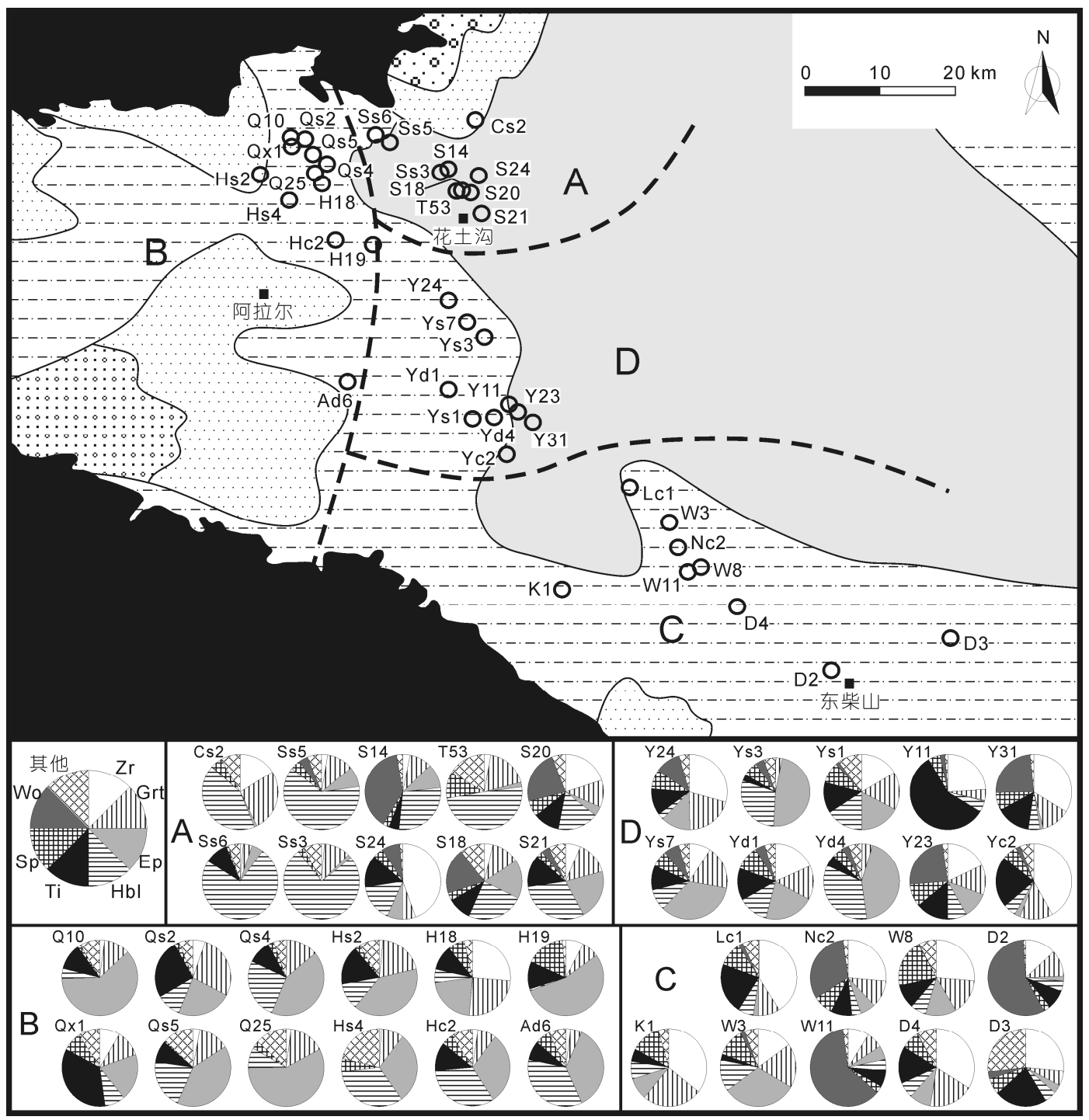

图 7 柴西南地区下干柴沟组上段沉积相展布及重矿物组合分布图

时期相比, 进一步增加. D区与 $\mathrm{B}$ 区相比, 绿帘石含量 较低, 角闪石含量较高, 榍石含量略高于 $\mathrm{B}$ 区.

狮子沟组及第四系沉积中, 重矿物组合整体上 均以角闪石、绿帘石和石榴石的重矿物组合为主(图 11), 其中 $\mathrm{A}$ 区显示角闪石含量较高, 绿帘石含量较 低; $\mathrm{B}$ 区则以绿宋石含量较高为特征; C区锆石和榍石 的含量较高; D区角闪石和绿帘石含量相当.

\section{4 柴西南新生代物源体系分析}

重矿物组合特征指示, 柴西南新生代沉积物整
体上以不稳定重矿物含量较高, 碎屑重矿物稳定指 数较低为特征, 指示了物源区经受的风化作用较弱, 整体上反映了近源特征. 同时, 不同区域重矿物组合 具有不同的特点，显示区域存在多个物源体系的共 同控制作用. 柴达木盆地新生代主要受阿尔金山、祁 连山及祁漫塔格-东昆仑山所围限, 盆地新生代物源 主要受三大山系的控制, 而柴西南位于新生代柴达 木盆地沉积中心南侧(Yin等, 2008b, 图 12), 受祁连 山物源影响有限, 因此柴西南地区主要存在阿尔金 和祁漫塔格-东昆仑两大潜在物源体系.

柴西南邻区地质简图显示(图12), 阿尔金山西段 


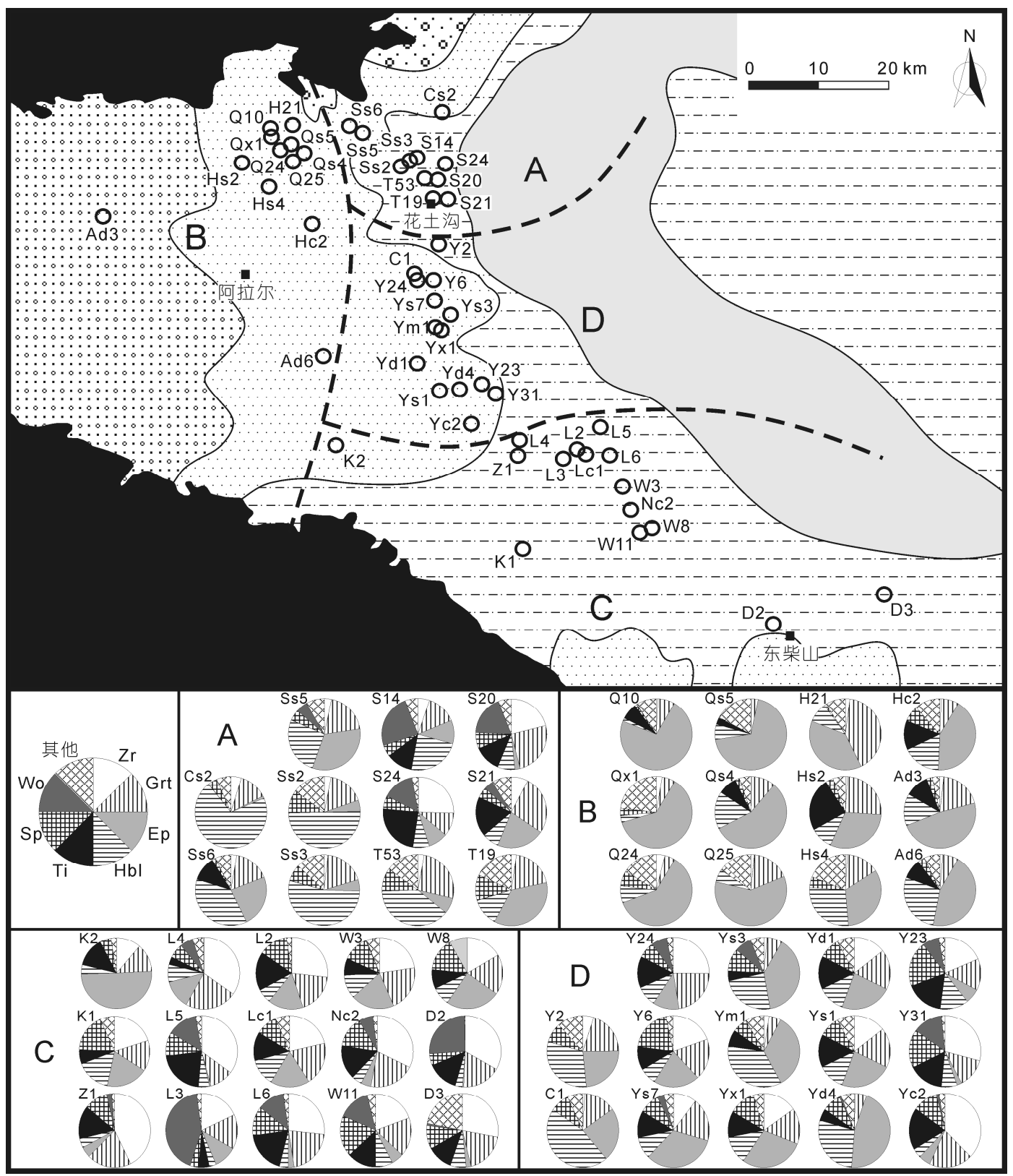

图 8 柴西南地区上干柴沟组沉积相展布及重矿物组合分布图

主要出露古元古界-太古界结晶基底, 同时有少量中 酸性侵入体及少量中-新元古界地层出露, 阿尔金山 中段, 侵入岩体及中-新元古界浅变质沉积岩出露的 面积显著增加, 而阿尔金山东段, 出露有大量古生界 灰岩、火山岩及碎屑岩地层, 同时仍有大量太古界、 元古界地层及中酸性侵入岩体出露. 祁漫塔格-东昆 仑地区主要以中酸性侵入岩、古生界及中生界地层为 主, 太古界及元古界地层出露范围较小。根据重矿物
组合特征的时空分布规律，结合潜在源区地层出露 特征，可以对柴西南物源体系进行如下划分.

柴西南干柴沟-狮子沟-花土沟地区(A区)位于阿 尔金山前，其物源受东昆仑山影响的可能性较小，吴 否等(2012，2013)对A区新生代下干柴沟组之上地层 古流向分析的结果也支持物源来自北方，因此A区物 源主要来自于阿尔金山方向. 古新世-早始新世路乐 河组一下柴沟组下段沉积时期，A区锆石和钛的 


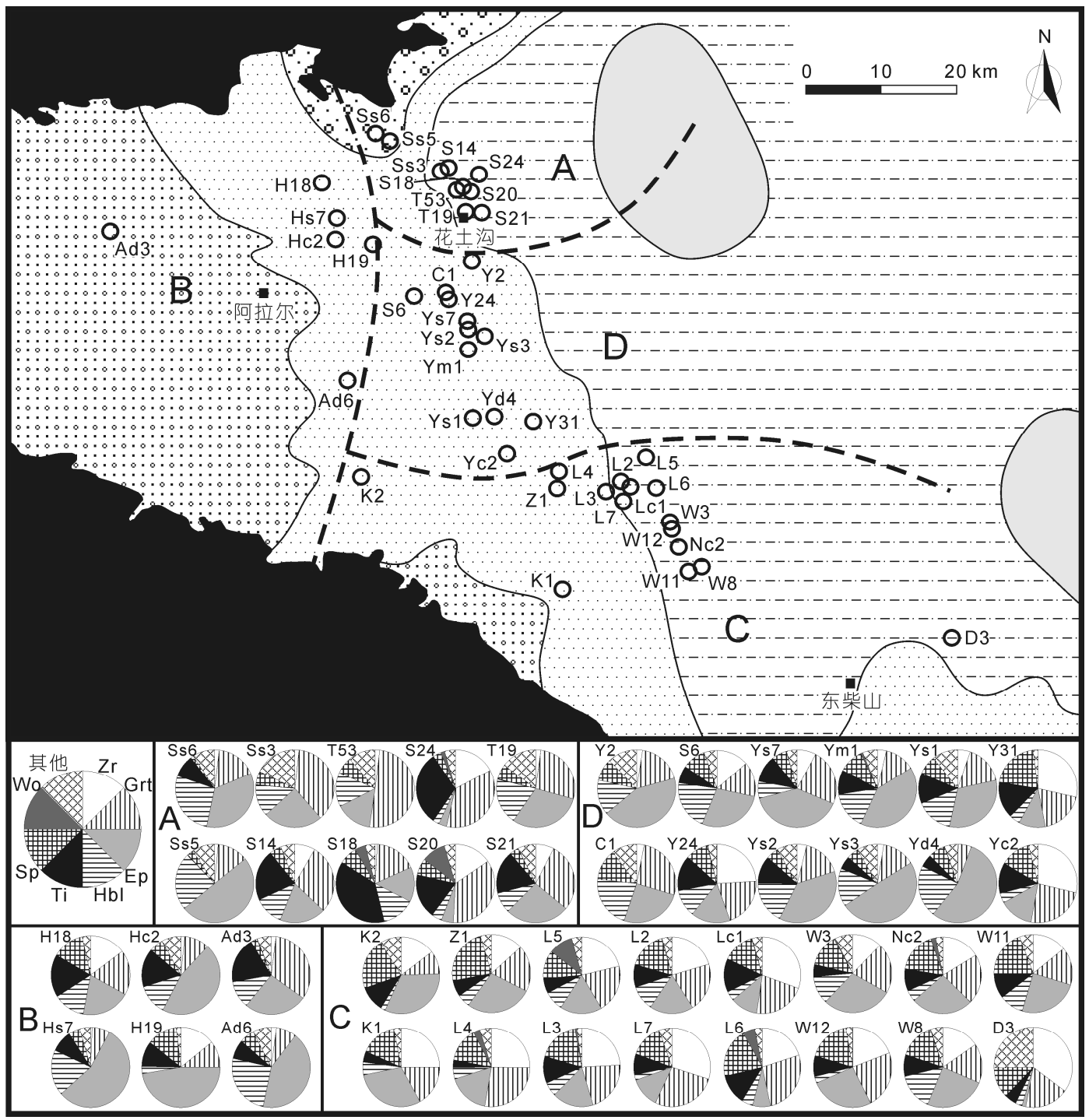

图 9 柴西南地区下油砂山组沉积相展布及重矿物组合分布图

氧化物等稳定矿物含量较高, 反映了沉积物经历了 较长时期的风化搬运过程, 整体上以相对远源物源 为主, 其中钛的氧化物主要来自中高级变质母岩, 反 应物源区可能与太古代结晶基底的剥露有关, 硅灰 石的出现指示了热液蚀变灰岩地层的出露, 同时由 于硅灰石的不稳定性, 说明存在近源物质的剥露, 而 整体上以远源物源为主的特征反映了近源隆起区的 隆起规模较小, 地形起伏较小, 对物源的贡献有限, 因此对整体重矿物组合特征的影响不大.

中晚始新世下干柴沟组上段沉积开始, A区重矿 物组合发生了明显变化, 角闪石、石榴石等含量显著
增加, 钛的氧化物、锆石等稳定矿物含量明显降低, 说明 $\mathrm{A}$ 区物源发生了明显的变化，近源区沉积物的供 给量显著增加并开始成为主要源区，导致了角闪石 等不稳定矿物在短暂的风化搬运过程中得以大量保 存，反映了古新世时期近源低洼隆起区自中晚始新 世开始进入快速隆升剥蚀阶段. 角闪石含量在下干 柴沟组上段及上干柴沟组样品中含量较高的特征可 能与阿尔金山太古界-古元古界结晶基底及中酸性侵 入岩的剥露有关，而下油砂山组以来绿宋石含量明 显增加，阿尔金山出露地层中，中-新元古界浅变质 岩由于经历了中、低级变质作用, 是绿帘石的重要潜 


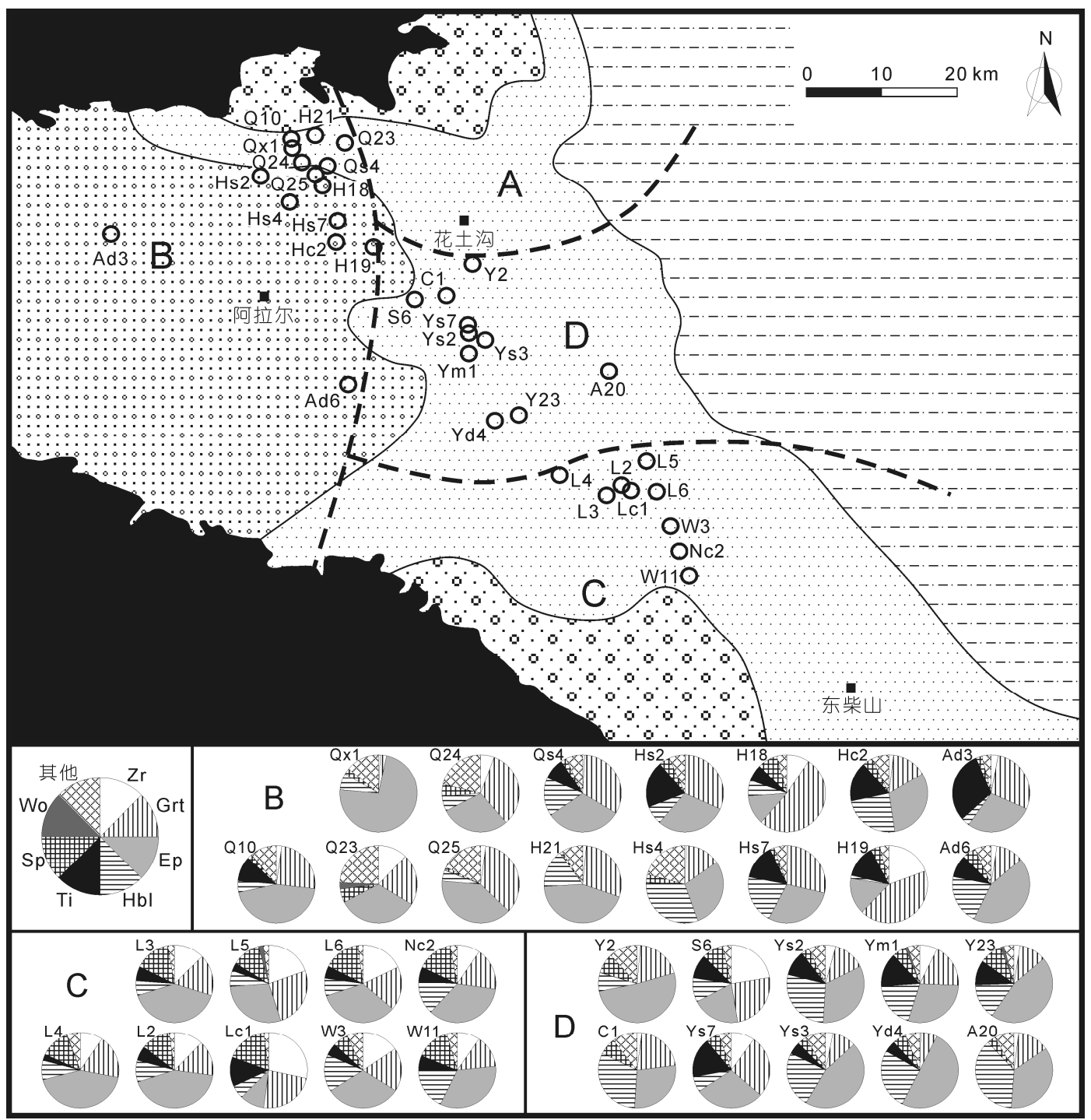

图 10 柴西南地区上油砂山组重矿物组合分布图

在母岩, 重矿物组合中绿帘石含量的增加很可能与 中-新元古界浅变质岩的剥露有关.

七个泉-红柳泉地区(B区)夹持于阿尔金和祁漫 塔格-东昆仑构造带的三角区域, 新生代重矿物组合 整体上以石榴石、绿帘石和角闪石等矿物为主, 整个 新生代重矿物组合变化不大, 其中不稳定矿物角闪 石和绿帘石的含量较高, 显示 $\mathrm{B}$ 区新生代一直以近源 快速堆积为特征, 物源母岩在经历较快的剥露、风 化、搬运过程后, 快速沉积, 从而保留了大量不稳定 矿物. 矿物组合中石榴石和角闪石是中酸性岩浆及 中高级变质岩中的常见矿物, 绿窝石则是中低级变
质和热液蚀变过程中的常见矿物, 指示物源区以中 低-中高级变质岩、岩浆岩母岩为主. 其重矿物组合特 征及区域地理位置特征均指示 $\mathrm{B}$ 区物源可能受阿尔 金和东昆仑双方向的控制.

绿草滩-东柴山-昆北地区(C区)位于祁漫塔格山 前，其新生代重矿物组合特征与 $\mathrm{A}$ 区及 $\mathrm{B}$ 区存在显著 差异, 整体上 $\mathrm{C} 区$ 稳定矿物锆石、钛的氧化物含量明 显高于 $\mathrm{A}$ 区及 $\mathrm{B}$ 区, 同时 $\mathrm{C}$ 区以硅灰石和榍石的出现 为特征, 指示物源中岩浆岩及灰岩地层出露范围较 大，而东昆仑大范围出露的中酸性岩体及古生界灰 岩地层与 $\mathrm{C}$ 区重矿物组合特征相吻合, 同时古生界及 


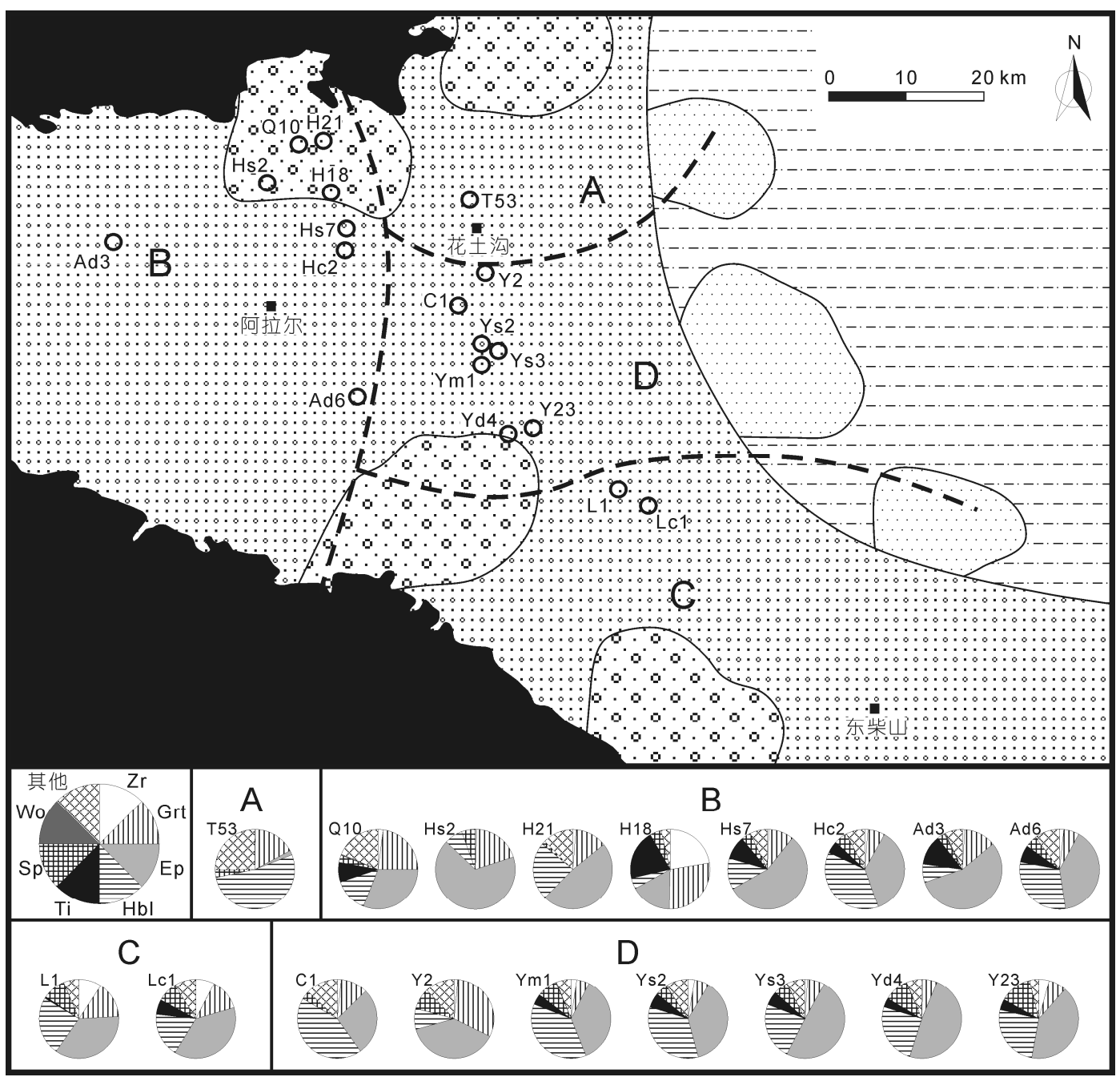

图 11 柴西南地区狮子沟组及第四系重矿物组合分布图

中生界地层的大量剥露引起的再旋回沉积也会使稳 定矿物含量增加, 与 $\mathrm{C}$ 区稳定矿物含量较高的特征相 一致, 说明 $\mathrm{C}$ 区物源主要来自祁漫塔格-东昆仑山方 向. 古近纪路乐河组-上干柴沟组沉积时期, C区重矿 物组合以锆石、钛的氧化物等稳定矿物为主, 反映了 沉积物经历了较长的风化、搬运过程, 物源区整体上 距离 $\mathrm{C} 区$ 较远. 而硅灰石的出现说明区域存在近源物 源的供给, 而整体以稳定矿物为主的特征则反映了 近源物源区对整个C区沉积过程的影响有限, 近源区 可能仅仅以地形平缓的低洼隆起形式存在, 仅为 $\mathrm{C}$ 区 提供少量碎屑物质供给. 晚渐新世-中新世下油砂山 组沉积以来, C区不稳定重矿物含量显著增加, 指示 近源区沉积物的供给比重明显增大, 近源区发生了
明显的快速剥露隆升.

跃进-油砂山地区(D区)古新世路乐河组沉积时 期, 重矿物组合与 $\mathrm{C} 区$ 相似. 早始新世下干柴沟组沉 积以来, D区具有典型混合物源的特征, 其重矿物组 合特征介于 $\mathrm{A}, \mathrm{B}$ 和 $\mathrm{C}$ 区之间, 其中不稳定矿物含量明 显低于 $\mathrm{A}$ 区和 $\mathrm{B}$ 区，而榍石、锆石等矿物的含量又明显 低于C区，说明D区受到了多个方向物源的共同影响.

综上所述，柴西南不同区域存在不同的物源特征. $\mathrm{A}$ 区新生代以来物源主要来自阿尔金山方向, 而重矿物 组合特征的不同可能与阿尔金断裂的走滑和阿尔金山 隆升导致的出露地层的变化有关. C区物源主要来自祁 漫塔格-东昆仑山方向, B区物源则显示受阿尔金山和 祁漫塔格-东昆仑山双方向物源的共同影响. 而 $\mathrm{D}$ 区 


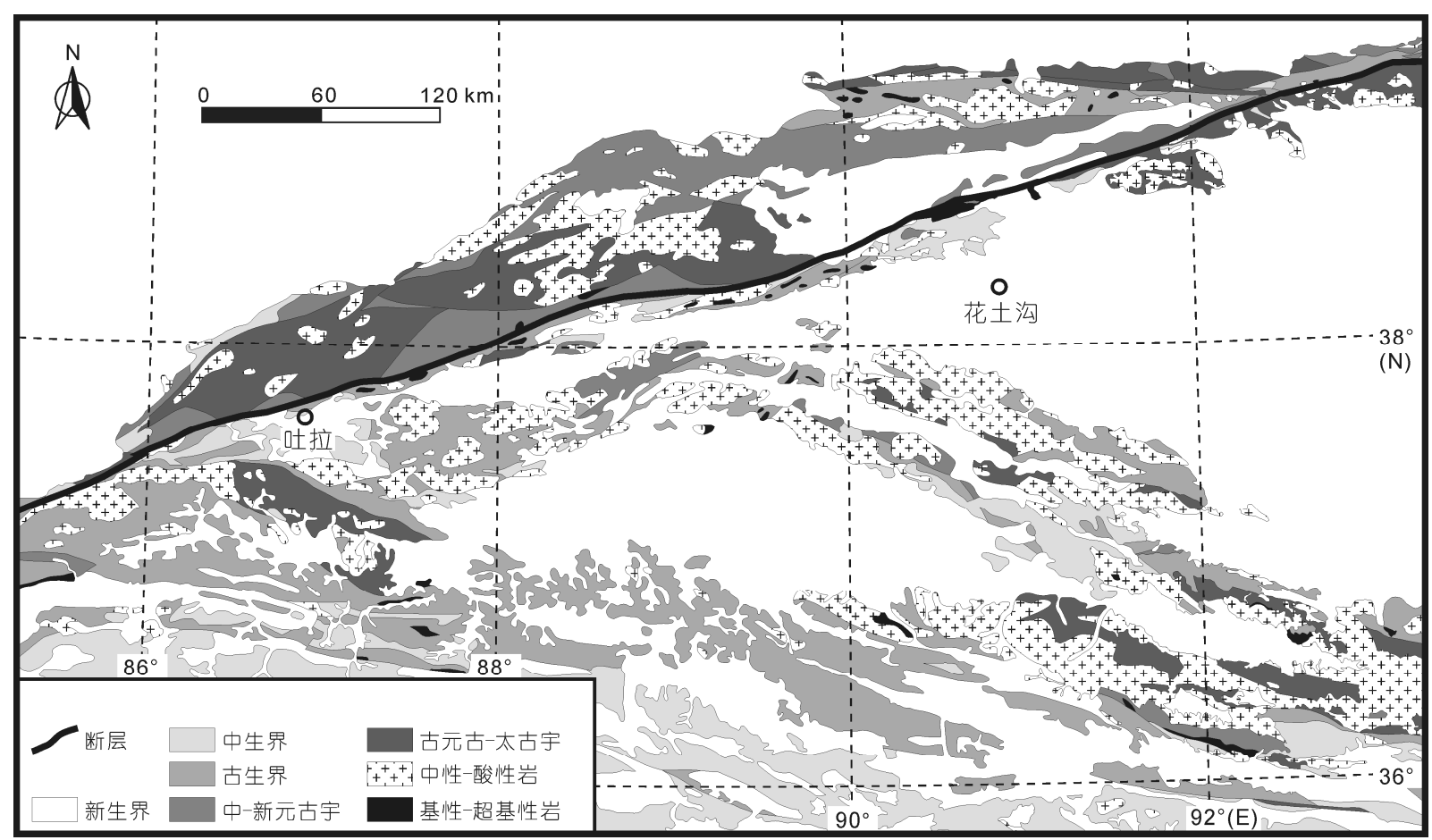

图 12 柴西南周缘阿尔金山及祁漫塔格-东昆仑山地区区域地质简图 据中国地质调查局(2004)

位于盆地腹部, 其物源明显受A, B和C区的共同影响.

\section{5 讨论}

柴西南新生代构造演化过程受阿尔金和祁漫塔 格-东昆仑两大断裂带的复杂构造作用控制, 盆地的 沉积充填特征和重矿物组合很好地记录了柴西南新 生代盆地的性质、盆地演化过程和物源体系特征, 从 而为分析阿尔金、祁漫塔格-东昆仑断裂带的构造演 化过程提供了载体。因此很多学者(Yin等, 2002, 2007; 吴否等, 2012, 2013; 肖安成等, 2013)都以柴西 南盆地沉积记录为介质来研究阿尔金和祁漫塔格-东 昆仑断裂带的构造演化过程.

阿尔金断裂位于柴达木盆地西北侧，虽然关于 阿尔金断裂的走滑过程，仍然存在较大的争议，但 是, 目前普遍认为阿尔金断裂新生代走滑位移量在 400 500 km(Ritts和Biffi, 2000; Yin等, 2002; Yue等, 2003, 2005; Darby等, 2005). 也就是说, 在柴西南地 区新生代早期，花土沟大致位于现今的吐拉地区附 近，此时盆地西北边界为阿尔金山西段. 在经历新生
代阿尔金断裂大规模走滑后，才移动至现今位置。

古新世-早始新世路乐河组及下干柴沟组下段沉 积时期(图13)，A区位于现今吐拉地区附近，其西北 侧为阿尔金山西段，而以稳定矿物为主的重矿物组 合特征说明这一时期阿尔金山西段不具有明显的正 地貌特征. Yin等(2008b)绘制的柴达木盆地新生代地 层厚度图(图12(A)和(B))显示路乐河组及下干柴沟组 下段，地层厚度等值线与阿尔金山斜交，也指示了这 一时期 $\mathrm{A}$ 区可以向西延伸，说明 $\mathrm{A}$ 区以远源物源为主. 重矿物组合中少量硅灰石等不稳定矿物的出现指示 存在少量近源物质的参与，说明阿尔金山西段此时 以低山丘陵地貌为特征. C区位于祁漫塔格山前, 其 重矿物组合同样以稳定矿物为主，说明这一时期祁 漫塔格-东昆仑断裂带构造活动微弱，祁漫塔格山不 具有明显的正地貌特征，物源经历了较长的搬运距 离，同时少量不稳定硅灰石矿物的出现指示存在少 量近源物质的供给, 说明近源区也以低矮的丘陵地 貌为主，地形起伏较小. B区位于阿尔金和祁漫塔格东昆仑断裂带夹持的三角区域，区域位置以及不同 于 $\mathrm{A}$ 区和 $\mathrm{C}$ 区的重矿物组合特征反映了 $\mathrm{B}$ 区物源主要 


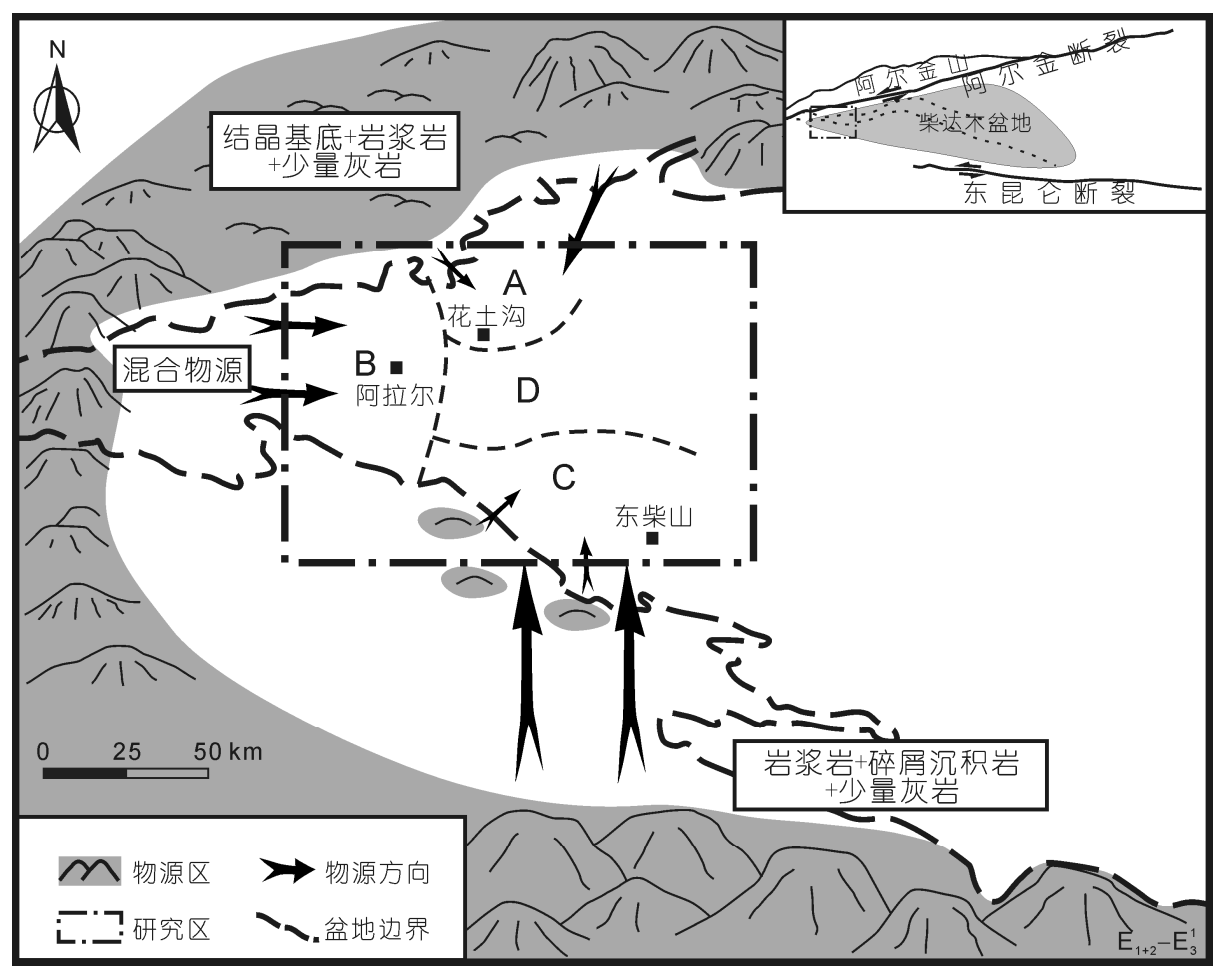

图 13 柴西南地区路乐河组一下干柴沟组下段沉积时期物源体系模式图

来自于阿尔金山和东昆仑山的混合物源区, 由于地 处两个构造带的相交位置, 构造活动较强, 因此重矿 物组合也显示以不稳定矿物为主的特征.

中晚始新世-渐新世下干柴沟组上段和上干柴沟 组沉积时期(图14), A区重矿物组合发生了明显的变 化, 角闪石含量显著增加, 指示近源的阿尔金山地区 发生了快速的隆升剥蚀. 吴否等(2012)的研究同样指 示了在下干柴沟组上段沉积时期, A区北部的阿哈提 隆起区发生了快速的隆升, 这一隆升时限与重矿物 组合突变的时间相吻合, 进一步证实了这一阶段阿 尔金山发生了快速的隆升. C区重矿物组合变化不大, 说明这一阶段祁漫塔格-东昆仑断裂带继承了其早期 特征, 构造活动较弱, 祁漫塔格山隆升作用不明显. $\mathrm{D}$ 区重矿物组合中, 不稳定矿物的含量有所增加, 与 阿尔金山的快速隆升相统一, 祁漫塔格-东昆仑断裂 带的构造稳定与阿尔金山的快速隆升, 导致了D区祁 漫塔格-东昆仑山物源比重的降低, 阿尔金山物源比 重的增加.

晚渐新世-中新世下油砂山组沉积以来(图15), A 区重矿物组合中角闪石含量有所减少, 而绿帘石含
量明显增加, 指示了中-新元古界地层的剥露面积的 明显增大. 阿尔金山西段较老的变质程度较高的结 晶基底出露面积较大, 中-新元古界较低变质程度的 地层出露较少，而阿尔金山中段中-新元古界地层出 露范围明显增加, 这一变化特征与重矿物组合由早 期角闪石含量较高向后期绿帘石含量增加的变化规 律相统一, 说明 $\mathrm{A}$ 区重矿物组合的变化与阿尔金断裂 的左行走滑导致的物源区的变化相一致. 区域地质 简图显示(图12), 吐拉东北约50 $\mathrm{km}$ 左右的山前地区 已经开始出露大范围中-新元古界地层, 反映古新世渐新世时期, 阿尔金断裂的走滑速率较为缓慢, 走滑 位移量较小，而超过 $300 \mathrm{~km}$ 的走滑位移主要发生在 晚渐新世-中新世以后，说明自晚渐新世-中新世以 来，阿尔金断裂的走滑速率明显增加，这一结果也与 吴否等 $(2012,2013)$ 阿尔金断裂中新世开始大规模走 滑的认识相统一. C区重矿物组合特征自下油砂山组 沉积时期以来，也发生了明显变化，不稳定矿物的含 量明显增加，反映了祁漫塔格-东昆仑断裂带构造活 动开始活跃，祁漫塔格山开始强烈隆升. 这一重矿物 变化时间与Yin等(2007)提出的晚渐新世柴西南南缘 


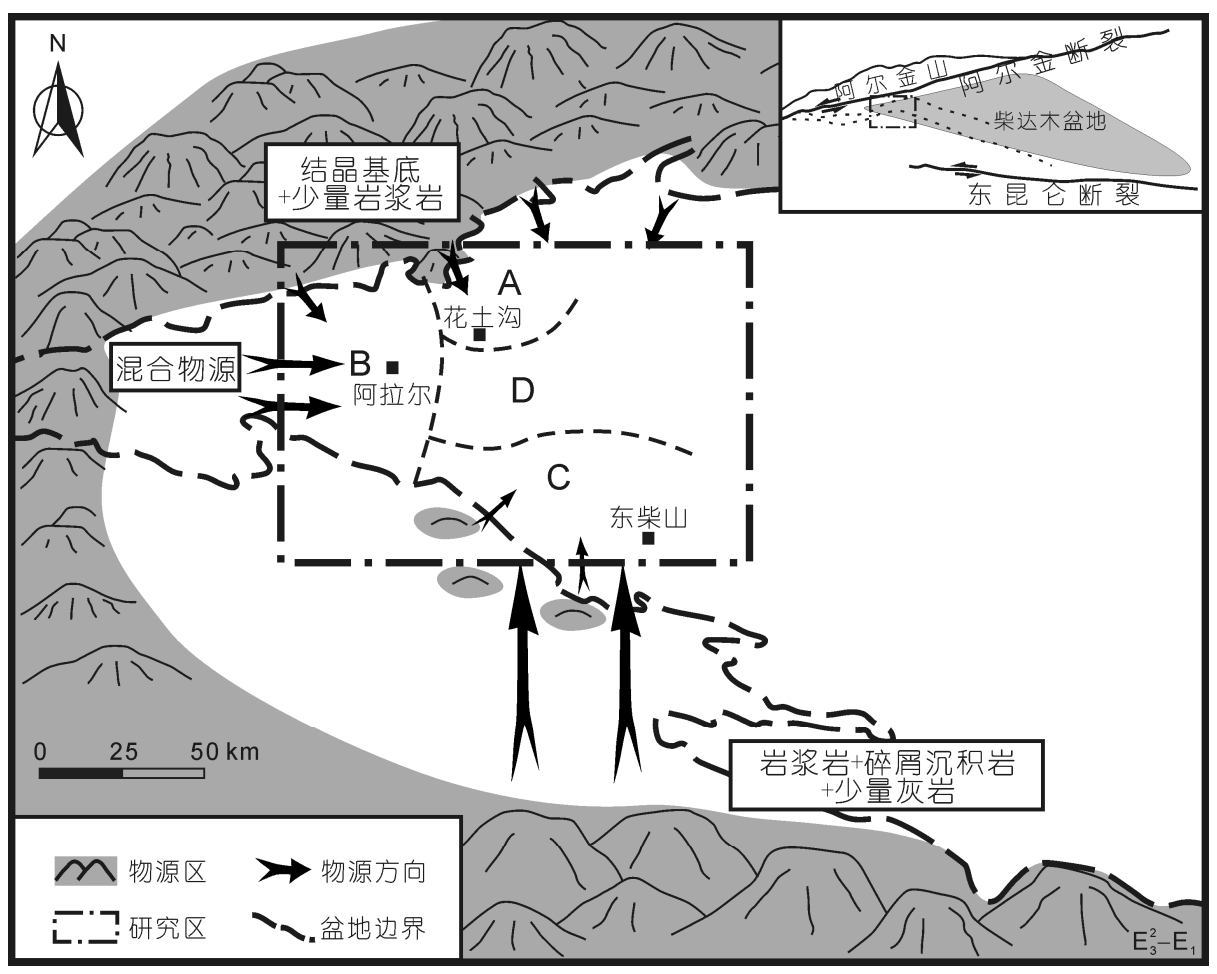

图 14 柴西南地区下干柴沟组上段-上干柴沟组沉积时期物源体系模式图

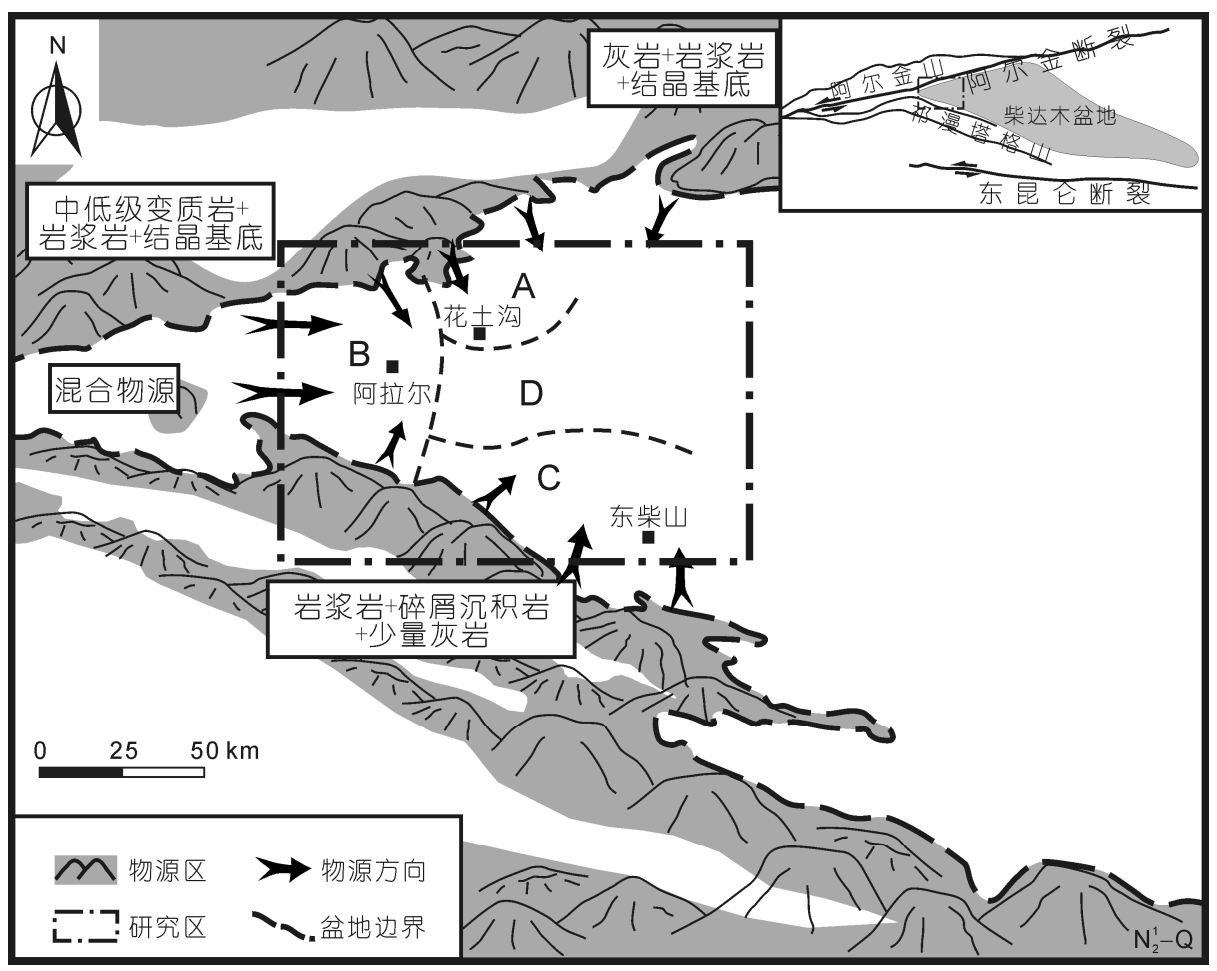

图 15 柴西南地区下油砂山组沉积时期至今物源体系模式图 
闭合时间统一, 进一步证实了祁漫塔格山自晚渐新 世以来的快速隆升和祁漫塔格-东昆仑断裂带的全面 活化.

印度和欧亚板块碰撞是控制我国西部新生代构 造演化的主要应力, Yin等(2002)对阿尔金断裂的分 析认为阿尔金断裂自 $50 \mathrm{Ma}$ 左右就已经开始活动, 并 认为阿尔金断裂的活动与印-藏碰撞及高原隆升同步, Yin等(2008a)也认为柴北缘地区发生了古新世-早始 新世时期的缩短变形, 存在着与印-藏碰撞同期的青 藏高原构造活动. 而柴西南地区重矿物分析的结果 指示，祁漫塔格-东昆仑断裂带古近纪时期构造活动 微弱，阿尔金山地区也以构造隆升为主，反应了柴西 南古近纪时期构造活动并不活跃, Yu等(2014)也通过 磁化率各向异性分析证明了柴达木盆地新生代早期 构造应力以南北向挤压应力为主, 且构造应力集中 在柴北缘地区, 柴西地区构造挤压应力微弱, 证明印藏碰撞早期青藏高原北缘构造应力主要集中在柴北 缘及南祁连山逆冲断裂带地区. 中新世以来, 祁漫塔 格-东昆仑断裂带的构造活动和阿尔金断裂的走滑活 动明显加剧, 柴西地区北东-南西向挤压应力也显著 加强(Yu等, 2014), 说明中新世时期青藏高原北缘进 入整体的构造活跃期.

\section{6 结论}

通过分析柴西南地区新生代重矿物组合特征, 得到如下结论.

(1) 柴西南新生代重矿物组合显示典型分区特 征, 指示区域存在阿尔金山和祁漫塔格-东昆仑山两 个主要物源区. 干柴沟-狮子沟-花土沟地区物源主要 来自阿尔金山地区, 其重矿物组合特征显示, 古新世-
早始新世时期，重矿物以锆石、钛的氧化物、硅灰石 组合为特征; 中晚始新世-渐新世时期, 重矿物以不 稳定矿物为主, 其中角闪石含量显著增加; 晚渐新世中新世以来, 重矿物仍以不稳定矿物为主, 但其中绿 帘石的含量增大，而角闪石的含量相应减小，七个泉红柳泉地区物源受阿尔金山和祁漫塔格-东昆仑山两 个方向的共同控制，重矿物组合以石榴石、绿帘石和 角闪石等矿物为主, 不稳定矿物的含量较高, 显示近 源快速堆积特征. 绿草滩-东柴山-昆北地区物源主要 来自祁漫塔格-东昆仑山地区, 古近纪时期重矿物组 合以锆石、钛的氧化物为主, 晚渐新世-中新世以来, 石榴石、绿帘石和角闪石等矿物含量明显增加. 跃进油砂山地区重矿物组合显示多区域混合的特点, 稳 定矿物锆石、钛的氧化物, 及不稳定矿物角闪石、绿 帘石等同时存在，受多方向物源的共同控制现象 明显.

（2）干柴沟-狮子沟-花土沟地区重矿物组合的变 化特征指示，古新世-早始新世时期，阿尔金山地形 起伏较小, 以低洼丘陵地貌为特征, 中晚始新世以 来, 阿尔金山开始快速隆升, 近源物源开始占据主导 地位. 整个古近纪时期，阿尔金断裂走滑速率缓慢， 走滑位移量较小, 构造活动以中晚始新世以来的隆 升作用为主；自晚渐新世-中新世时期开始，阿尔金 断裂的走滑速率明显增加, 并导致新近纪以来阿尔 金断裂的走滑位移量超过 $300 \mathrm{~km}$.

(3) 绿草滩-东柴山-昆北地区重矿物组合的变化 特征指示，古近纪时期，祁漫塔格-东昆仑断裂带处 于构造稳定阶段，区域构造活动微弱，祁漫塔格山地 区以低洼丘陵地貌为特征, 地形起伏不大, 晚渐新世中新世以来, 祁漫塔格-东昆仑断裂带构造活动开始活 跃，同时祁漫塔格山也开始进入快速隆升剥蚀阶段。

\section{参考文献}

陈正乐，宫红良，李丽，等. 2006. 阿尔金山脉新生代隆升-剥露过程. 地学前缘, 13: 91-102

付玲, 关平, 简星, 等. 2012. 柴达木盆地路乐河组粗碎屑沉积成因与青藏高原隆升时限. 天然气地球科学, 23: 833-840

惠博, 伊海生, 夏国清, 等. 2011. 柴达木盆地西部新生代沉积演化特征. 中国地质, 38: 1274-1281

蒋宏快, 于炳松, 王黎栋, 等. 2003. 柴达木盆地西部红狮凹陷第三系下干柴沟组沉积相分析. 沉积学报, 21: 391-397

刘群明，陈开远，王键，等. 2011. 柴达木盆地三湖坳陷第四系重矿物物源分析. 现代地质, 25: 315-321

刘永江, Neubauer F, 葛肖虹, 等. 2007. 阿尔金断裂带年代学和阿尔金山隆升. 地质科学, 42: 134-146 
刘志宏, 万传彪, 杨建国, 等. 2005. 柴达木盆地北缘地区新生代构造特征及变形规律. 地质科学, 40: 404-414

柳祖汉, 吴根耀, 杨孟达, 等. 2006. 柴达木盆地西部新生代沉积特征及其对阿尔金断裂走滑活动的响应. 地质科学, 41: 344-354

吕宝风, 张越青, 杨书逸. 2011. 柴达木盆地构造体系特征及其成盆动力学意义. 地质论评, 57: 167-174

马达德, 寿建峰, 胡勇, 等. 2005. 柴达木盆地柴西南区碎屑岩储层形成的主控因素分析. 沉积学报, 23: 589-595

任收麦, 葛肖虹, 杨振宇, 等. 2006. ${ }^{36} \mathrm{Cl}$ 断代法应用于青藏高原末次快速隆升构造事件的研究. 地质学报, 80: 1110-1117

王成善, 李祥辉. 2003. 沉积盆地分析原理与方法. 北京: 高等教育出版社. 378

王建刚, 胡修棉. 2008. 砂岩副矿物的物源区分析新进展. 地质论评, 54: 670-678

王艳清，宫清顺，夏志远，等. 2012. 柴达木盆地西部地区渐新世沉积物源分析. 中国地质, 39: 426-435

吴婵, 阎存风, 李海兵, 等. 2013. 柴达木盆地西部新生代构造演化及其对青藏高原北部生长过程的制约. 岩石学报, 29: 2211-2222

吴朝东, 林畅松, 申延平, 等. 2005. 库车坳陷侏罗系砂岩组分和重矿物组合特征及其源区属性. 自然科学进展, 15: 291-297

吴否, 巩庆霖，覃素华. 2013. 阿尔金断裂新生代大规模走滑起始时间的厘定. 岩石学报, 29: 2837-2850

吴否, 肖安成, 汪立群, 等. 2012. 阿尔金断裂中段南侧东西向隆起的形成及对阿尔金山新生代隆升机制的启示. 中国科学: 地球科学, 42: $1836-1876$

肖安成, 吴否, 李洪革, 等. 2013. 阿尔金断裂新生代活动方式及其与柴达木盆地的耦合分析. 岩石学报, 29: 2826-2836

徐亚军, 杜远生, 杨江海. 2007. 沉积物源分析研究进展. 地质科技情报, 26: 26-32

尹成明, 李伟民, Andrea R, 等. 2007. 柴达木盆地新生代以来的气候变化研究: 来自碳氧同位素的证据. 吉林大学学报(地球科学版), 37: 901-907

袁四化, 刘永江, 葛肖虹, 等. 2008. 青藏高原北缘的隆升时期——来自阿尔金山和柴达木盆地的证据. 岩石矿物学杂志, 27: 413-421

赵加凡, 陈小宏, 杜业波. 2004. 柴达木第三纪湖盆沉积演化史. 石油勘探与开发, 31: 41-44

中国地质调查局，成都地质矿产研究所. 2004. 青藏高原及邻区地质图. 成都: 成都地图出版社

中国石油天然气总公司. 1997. 沉积岩重矿物分析与鉴定方法. SY/T6336-1997

Andò S, Garzanti E, Padoan M, et al. 2012. Corrosion of heavy minerals during weathering and diagenesis: A catalog for optical analysis.

Sediment Geol, 280: 165-178

Burchfiel B C, Deng Q D, Molnar P, et al. 1989. Intracrustal detachment within zones of continental deformation. Geology, 17: 748-752

Chen W P, Chen C Y, Nábelek J L. 1999. Present-day deformation of the Qaidam basin with implications for intra-continental tectonics. Tectonophysics, 305: 165-181

Darby B J, Ritts B D, Yue Y J, et al. 2005. Did the Altyn Tagh fault extend beyond the Tibetan Plateau? Earth Planet Sci Lett, 240: 425-435

DeCelles P G, Robinson D M, Zandt G. 2002. Implications of shortening in the Himalayan fold-thrust belt for uplift of the Tibetan Plateau. Tectonics, 21: 1062

Dupont-Nivet G, Butler R F, Yin A, et al. 2002. Paleomagnetism indicates no Neogene rotation of the Qaidam Basin in northern Tibet during Indo-Asian collision. Geology, 30: 263-266

Dupont-Nivet G, Robinson D, Butler R F, et al. 2004. Concentration of crustal displacement along a weak Altyn Tagh fault: Evidence from paleomagnetism of the northern Tibetan Plateau. Tectonics, 23: TC1020

Fang X M, Zhang W L, Meng Q Q, et al. 2007. High-resolution magnetostratigraphy of the Neogene Huaitoutala section in the eastern Qaidam Basin on the NE Tibetan Plateau, Qinghai Province, China and its implication on tectonic uplift of the NE Tibetan Plateau. Earth Planet Sci Lett, 258: 293-306

Garzanti E, Resentini A, Vezzoli G, et al. 2012. Forward compositional modeling of Alpine orogenic sediments. Sediment Geol, 280: 149-164

Garzanti E, Vermeesch P, Andò S, et al. 2013. Provenance and recycling of Arabian desert sand. Earth-Sci Rev, 120: 1-19

Harrison T M, Copeland P, Kind W S F, et al. 1992. Raising Tibet. Science, 255: 1663-1670

Hubert J F. 1962. A zircon-tourmaline-rutile maturity index and the interdependence of the composition of heavy mineral assemblages with the gross composition and texture of sandstones. J Sediment Res, 32: 440-450

Jolivet M, Brunel M, Seward D, et al. 2001. Mesozoic and Cenozoic tectonics of the northern edge of the Tibetan plateau: Fssion-track constraints. Tectonophysics, 343: 111-134

Jolivet M, Brunel M, Seward D, et al. 2003. Neogene extension and volcanism in the Kunlun Fault Zone, northern Tibet: New constraints on the age of the Kunlun Fault. Tectonics, 22: 1052

Kapp P, Yin A, Manning G E, et al. 2003. Tectonic evolution of the Mesozoic blue schist-bearing Qiangtang metamorphic belt, central Tibet. Tectonics, 22: 1043

Mange M A, Maurer H F W. 1992. Heavy Minerals in Color. London: Chapman and Hall. 147

Morton A C. 1985. A new approach to provenance studies: Electron microprobe analysis of detrital garnets from Middle Jurassic sandstones of the northern North Sea. Sedimentology, 32: 553-566 
Morton A C, Hallsworth C. 1994. Identifying provenance-specific features of detrital heavy mineral assemblages in sandstones. Sediment Geol, 90: $241-256$

Morton A C, Hallsworth C R. 1999. Processes controlling the composition of heavy mineral assemblages in sandstones. Sediment Geol, 124: 3-29

Owens T J, Zandt G. 1997. Implications of crustal property variations for models of Tibetan plateau evolution. Nature, 387: 37-43

Pettijohn F J. 1957. Sedimentary Rocks. 2nd ed. New York: Harper \& Brothers. 718

Pettijohn F J, Potter P E, Siever R. 1987. Sand and Sandstone. 2nd ed. New York: Springer. 553

Rieser A B, Neubauer F, Liu Y J, et al. 2005. Sandstone provenance of north-western sectors of the intracontinental Cenozoic Qaidam basin, western China: Tectonic vs. climatic control. Sediment Geol, 177: 1-18

Rieser A B, Bojar A V, Neubauer F, et al. 2009. Monitoring Cenozoic climate evolution of northeastern Tibet: Stable isotope constraints from the western Qaidam basin, China. Int J Earth Sci, 98: 1063-1075

Ritts B D, Biffi U. 2000. Magnitude of post-Middle Jurassic (Bajocian) displacement on the central Altyn Tagh fault system, northwest China. Geol Soc Am Bull, 112: 61-74

Royden L H, Burchfiel B C, van der Hilst R D. 2008. The geological evolution of the Tibetan Plateau. Science, 321: 1054-1058

Song B W, Zhang K X, Lu J F, et al. 2013. The middle Eocene to early Miocene integrated sedimentary record in the Qaidam Basin and its implications for paleoclimate and early Tibetan Plateau uplift. Can J Earth Sci, 50: 183-196

Sun Z M, Yang Z Y, Pei J L, et al. 2005. Magnetostratigraphy of Paleogene sediments from northern Qaidam Basin, China: Implications for tectonic uplift and block rotation in northern Tibetan plateau. Earth Planet Sci Lett, 237: 635-646

Tapponnier P, Xu Z Q, Roger F, et al. 2001. Oblique stepwise rise and growth of the Tibet plateau. Science, 294: 1671-1677

Wang C S, Gao R, Yin A, et al. 2011. A mid-crustal strain-transfer model for continental deformation: A new perspective from high-resolution deep seismic-reflection profiling across NE Tibet. Earth Planet Sci Lett, 306: 279-288

Weltje G J, von Eynatten H. 2004. Quantitative provenance analysis of sediments: Review and outlook. Sediment Geol, 171: 1-11

Yin A, Harrison T M. 2000. Geologic evolution of the Himalayan-Tibetan orogen. Annu Rev Earth Planet Sci, 28: 211-280

Yin A, Rumelhart P E, Butler R, et al. 2002. Tectonic history of the Altyn Tagh fault system in northern Tibet inferred from Cenozoic sedimentation. Geol Soc Am Bull, 114: 1257-1295

Yin A, Dang Y Q, Zhang M, et al. 2007. Cenozoic tectonic evolution of Qaidam basin and its surrounding regions (Part 2): Wedge tectonics in southern Qaidam basin and the Eastern Kunlun Range. In: Sears J W, Harms T A, Evenchick C A, eds. Whence the Mountains? Inquiries into the Evolution of Orogenic Systems: A Volume in Honor of Raymond A. Geol Soc Am Spec Pap, 433: 369-390

Yin A, Dang Y Q, Wang L C, et al. 2008a. Cenozoic tectonic evolution of Qaidam basin and its surrounding regions (Part 1): The southern Qilian Shan-Nan Shan thrust belt and northern Qaidan basin. Geol Soc Am Bull, 120: 813-846

Yin A, Dang Y Q, Zhang M, et al. 2008b. Cenozoic tectonic evolution of the Qaidam basin and its surrounding regions (Part 3): Structural geology, sedimentation, and regional tectonic reconstruction. Geol Soc Am Bull, 120: 847-876

Yu X J, Huang B C, Guan S W, et al. 2014. Anisotropy of magnetic susceptibility of Eocene and Miocene sediments in the Qaidam Basin, Northwest China: Implication for Cenozoic tectonic transition and depocenter migration. Geochem Geophys Geosyst, 15: 2095-2108

Yue Y J, Ritts B D, Graham S A, et al. 2003. Slowing extrusion tectonics: Lowered estimate of post-Early Miocene slip rate for the Altyn Tagh Fault. Earth Planet Sci Lett, 217: 111-122

Yue Y J, Graham S A, Ritts B D, et al. 2005. Detrital zircon provenance evidence for large-scale extrusion along the Altyn Tagh Fault. Tectonophysics, 406: 165-178

Zhang K X, Wang G C, Xu Y D, et al. 2013. Sedimentary evolution of the Qinghai-Tibet Plateau in Cenozoic and its response to the uplift of the plateau. Acta Geol Sin, 87: 555-575

Zhu L P, Helmberger D V. 1998. Moho offset across the northern margin of the Tibetan Plateau. Science, 281: 1170-1172 